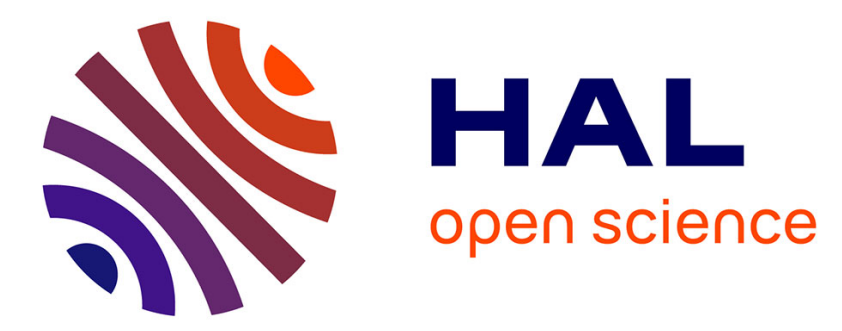

\title{
Thermodynamic uptake of atmospheric CO2 in the oligotrophic and semiarid São Francisco estuary (NE Brazil)
}

Gwenaël Abril, Bruno Libardoni, Nilva Brandini, Luiz Cotovicz, Paulo R.P. Medeiros, Geórgenes Cavalcante, Bastiaan Knoppers

\section{To cite this version:}

Gwenaël Abril, Bruno Libardoni, Nilva Brandini, Luiz Cotovicz, Paulo R.P. Medeiros, et al.. Thermodynamic uptake of atmospheric CO2 in the oligotrophic and semiarid São Francisco estuary (NE Brazil). Marine Chemistry, 2021, 233, pp.103983. 10.1016/j.marchem.2021.103983 . hal-03375517

\section{HAL Id: hal-03375517 https://hal.science/hal-03375517}

Submitted on 14 Oct 2021

HAL is a multi-disciplinary open access archive for the deposit and dissemination of scientific research documents, whether they are published or not. The documents may come from teaching and research institutions in France or abroad, or from public or private research centers.
L'archive ouverte pluridisciplinaire HAL, est destinée au dépôt et à la diffusion de documents scientifiques de niveau recherche, publiés ou non, émanant des établissements d'enseignement et de recherche français ou étrangers, des laboratoires publics ou privés. 
1 Thermodynamic uptake of atmospheric $\mathrm{CO}_{2}$ in the oligotrophic and semi-arid São Francisco estuary (NE Brazil).

6 Gwenaël Abril ${ }^{1,2, *}$, Bruno G. Libardoni², Nilva Brandini ${ }^{2}$, Luiz C. Cotovicz Jr. ${ }^{3}$, Paulo R. P.

7 Medeiros ${ }^{4}$, Geórgenes H. Cavalcante ${ }^{5,6}$, and Bastiaan A. Knoppers ${ }^{2}$

8

$9{ }^{1}$ Laboratoire de Biologie des Organismes et Ecosystèmes Aquatiques (BOREA), Muséum

10 National d'Histoire Naturelle, FRE 2030, CNRS, MNHN, IRD, SU, UCN, UA, Paris, France.

$11{ }^{2}$ Programa de Geoquímica, Universidade Federal Fluminense, Niterói, RJ, Brazil

$12{ }^{3}$ Instituto de Ciências do Mar, Universidade Federal do Ceará, Fortaleza, Ceará, Brazil

$13{ }^{4}$ Instituto de Geografia Desenvolvimento e Meio Ambiente, Universidade Federal de Alagoas,

14 Maceio, AL, Brazil

$15{ }^{5}$ Instituto de Ciências Atmosféricas, Universidade Federal de Alagoas, Maceio, AL, Brazil

$16{ }^{6}$ Department of Biology, Chemistry and Environmental Sciences, College of Arts and

17 Sciences, American University of Sharjah, Sharjah, United Arab Emirates.

18

* Corresponding author gwenael.abril@mnhn.fr

24 Submitted to Marine Chemistry, revised version 
31 Estuarine carbonate chemistry predicts that thermodynamic equilibration during the mixing of freshwater with seawater will generate a carbon dioxide $\left(\mathrm{CO}_{2}\right)$ sink for the case of warm and poorly buffered tropical rivers. The São Francisco River estuary has historically become oligotrophic, after the construction on its watershed of a series of hydroelectric dams, where organic matter and nutrients are retained. During two cruises in late winter (Aug. 2014) and early summer (Nov. 2015), dissolved inorganic carbon (DIC) and total alkalinity (TA) increased linearly with salinity in the main estuarine channel, where the mixing time of water was half a day, and showed a close to conservative behaviour. In the main channel, water partial pressure of $\mathrm{CO}_{2}\left(p \mathrm{CO}_{2}\right)$ recorded at 1min frequency, followed an asymmetric bell-shaped trend versus salinity, close to the curve predicted by thermodynamic conservative mixing of freshwater DIC and TA with seawater DIC and

chlorophyll concentrations, a $\mathrm{pCO}_{2}$ diurnal change of about 60 ppmv suggested the occurrence of

photosynthesis in summer. At salinities above 3, under-saturated $\mathrm{pCO}_{2}$ values (down to $225 \mathrm{ppmv}$ in winter and neap tides) and invasion of atmospheric $\mathrm{CO}_{2}$ of $0.38-1.70 \mathrm{mmol} \mathrm{m}^{-1} \mathrm{~h}^{-1}$ occurred because of predominating thermodynamics during estuarine mixing. In winter and neap tides, higher river discharge, intense estuarine mixing, lower temperatures and limited tidal pumping resulted in observed $p \mathrm{CO}_{2}$ different from theoretical conservative $p \mathrm{CO}_{2}$ by less than $3 p p m v$ at salinities $>3$. Conversely, in summer and spring tides, recorded $p \mathrm{CO}_{2}$ values were on average $+43 \pm 35$ ppmv above the conservative mixing curve, when tidal pumping, $\mathrm{CO}_{2}$ invasion and surface heating were more significant in the mixing zone, but not sufficient to offset the thermodynamic uptake of atmospheric $\mathrm{CO}_{2}$. By combining carbonate chemistry with estuarine mixing modelling and gas exchange calculations, we estimate that heating contributed to about $15 \%$ and gas exchange to about $10 \%$ of the positive $\mathrm{pCO}_{2}$ deviation from conservative mixing during summer. The remaining $75 \%$ of the deviation was maximum at ebb tides and within a salinity ranges consistent with the occurrence of tidal pumping from marches and mangrove soils. Indeed, in the mangrove channel, water were supersaturated with $\mathrm{pCO}_{2}$ values of $976 \pm 314 \mathrm{ppmv}$, while in the main channel, highest positive $\mathrm{pCO}_{2}$ deviations from conservative mixing (up to $+100 p p m v$ during several hours) occurred at ebb tides. An important finding was that, in the São Francisco, the 
59 thermodynamic and biological processes compete with each other to $\mathrm{CO}_{2}$ fluxes both at low

60 salinities where evasion and autotrophy occur, and at high salinities where invasion, heterotrophy

61 and tidal pumping occur. Our study suggests that carbonate thermodynamics during mixing is a

62 key process that has been overlooked in estuarine studies, although it can generate important air-

63 water $\mathrm{CO}_{2}$ exchange and contribute significantly to the carbon budget of estuaries and river 64 plumes.

65

66 Keywords

67 Carbonate equilibria, estuarine mixing, tidal pumping, heterotrophy, heating, gas exchange 68

69 


\section{Introduction}

71 The necessity of reducing uncertainties on global estimates of $\mathrm{CO}_{2}$ sources and sinks on Earth has promoted research on the carbon cycle in estuarine and coastal ecosystems particularly during the last three decades (Wollast, 1991; Smith and Hollibaugh, 1993; Frankignoulle et al., 1998; Cai, 2011; Borges and Abril, 2011; Bauer et al., 2013; Dinauer and Mucci, 2017, Maher et al., 2018). Despite their small surface areas, estuaries have been identified as a hotspot of $\mathrm{CO}_{2}$ emissions, able to offset a large part of the $\mathrm{CO}_{2}$ sink on the continental shelves (Chen and Borges, 2009). This conclusion was based on field observations in temperate and boreal regions, where estuaries have been recognized as $\mathrm{CO}_{2}$ sources and as heterotrophic ecosystems, that is, with a negative net ecosystem production (NEP) (Smith and Hollibaugh, 1993; Borges and Abril, 2011). Upper estuarine regions with generally well-mixed channels are almost always net heterotrophic, supersaturated in $\mathrm{CO}_{2}$ and a strong source of $\mathrm{CO}_{2}$ to the atmosphere (Frankignoulle et al., 1998;

The global $\mathrm{CO}_{2}$ emissions from estuaries suffer from large uncertainties due to spatial and temporal heterogeneity (Chen and Borges, 2009). In most studies, the relationship between NEP and $\mathrm{CO}_{2}$ fluxes could not be established quantitatively because many processes other than community respiration and primary production can alter the partial pressure of $\mathrm{CO}_{2}\left(p \mathrm{CO}_{2}\right)$ and the direction and intensity of the air-sea $\mathrm{CO}_{2}$ flux in estuaries (Borges, 2005). For instance, in eutrophic estuaries, nitrification can titrate $\mathrm{TA}$ to $\mathrm{CO}_{2}$, contrarily to carbonate dissolution that can consume $\mathrm{CO}_{2}$ and generate TA (Frankignoulle et al., 1996; Abril and Frankignoulle, 2001; Abril et al., 2003; Cotovicz et al., 2021). Some dissolved $\mathrm{CO}_{2}$ transported laterally from freshwaters or tidal marshes and mangroves is ventilated in river-dominated and/or macrotidal estuaries (Abril et al., 2000; Neubauer and Anderson, 2003; Borges et al., 2003; 2006; Cai, 2011). In general, advection of surface or sub-surface waters enriched in DIC, and/or biodegradable organic carbon (OC), as 
well as the presence of vegetation at the land-water interface, complicates the calculation of NEP and its relationship with $\mathrm{CO}_{2}$ fluxes (Borges, 2005; Cai, 2011; Borges and Abril, 2011; Santos et al., 2018; Maher et al., 2018).

In estuaries, water $p \mathrm{CO}_{2}$ is also strongly modified by the displacement of the acid-base equilibria of the carbonate system during the mixing of freshwater with seawater. As a consequence, the concentrations of bicarbonate $\left(\mathrm{HCO}_{3}{ }^{-}\right)$and carbonate $\left(\mathrm{CO}_{3}{ }^{2-}\right)$ ions, as well as $\mathrm{pCO}_{2}$ in a mixture of two waters with different salinities and temperatures, are very different from the arithmetic mean of these parameters in the two waters. In their pioneer theoretical work, Whitfield and Turner (1986) applied newly published carbonate dissociation and gas solubility constants to calculate the theoretical distribution of $p \mathrm{CO}_{2}$ along the salinity gradient induced by the conservative mixing of DIC and TA from the freshwater and marine end-members. These authors showed that "the mixing of river water and sea water [...] tends to produce significant disequilibrium between the estuary and the atmosphere which may manifest itself as a deficit or as an excess of carbon dioxide, depending on the $\mathrm{pH}$ and alkalinity of the river water." However, in recent years, studies rarely consider in detail carbonate thermodynamic during mixing as a potential driver of estuarine $\mathrm{CO}_{2}$ fluxes, although it can generate some atmospheric $\mathrm{CO}_{2}$ release or uptake additional to NEP (Cai et al., 2013; Lefèvre et al., 2017; Delaigue et al., 2020; Cotovicz et al., 2020). Most studies have focused on the correlation between biological components of $\mathrm{NEP}$ and $\mathrm{CO}_{2}$ fluxes (Borges and Abril 2011), and lateral C fluxes induced by tidal inundation and pumping (Cai, 2011; Maher et al., 2013; 2018). In the Amazon plume, a large part of the $\mathrm{CO}_{2}$ sink at salinities higher than 17 could be attributed to thermodynamics, but unfortunately no $\mathrm{pCO}_{2}$ field data are available at salinities lower than 17 (Körtzinger, 2003; Cai et al., 2013; Lefèvre et al., 2017). Recently, Cotovicz et al. (2020) reported a $\mathrm{CO}_{2}$ sink in the estuarine delta of the Paraiba do Sul River induced by a combination of carbonate thermodynamics, ecosystem metabolism and temperature effects. Although it is essential in the open ocean, the role of surface water heating or cooling on $\mathrm{CO}_{2}$ fluxes is poorly documented in estuarine waters. In tropical and sub-tropical coastal systems, surface heating and evaporation can have a large impact on $\mathrm{CO}_{2}$ water-air fluxes (Yao and $\mathrm{Hu}$ 2017; Cotovicz et al., 2020; Yao et al. 2020). 
In the present study, we report high resolution data of the carbonate system in a tropical,

129 oligotrophic estuary with short mixing time, where thermodynamics alone explains a large part of

130 the well-defined $p \mathrm{CO}_{2}$ distribution. Owing to warm temperatures and low TA at the river end-

131 member, the São Francisco estuary presents conditions that theoretically generate $\mathrm{CO}_{2}$ invasion

132 during estuarine mixing, even when supersaturation prevails in the river, a case similar to large

133 tropical rivers such as the Amazon and the Congo (Cai et al., 2013). The oligotrophic character of

134 the estuary and the short mixing time make chemical and physical processes predominate over

135 biological processes. The estuary is also connected to a small mangrove forest that may export

136 dissolved carbon to waters (Maher et al., 2013), and is subjected to important heating owing to the

137 semi-arid evaporative conditions in summer.

138

\section{2. Material and methods}

$140 \quad 2.1$. Study area

141 The São Francisco River (Fig. 1) drains an area of $634000 \mathrm{~km}^{2}$ in Brazil that includes Pleistocene142 Holocene plains (Dominguez, 1996). Precambrian rocks of the Brazilian shield dominate the 143 geology of the basin, and the climate varies from tropical humid in the upper and lower regions, to 144 semiarid in the middle region (Bernardes, 1951). The River course has been progressively 145 intensively modified between the 50's and the 90 's by the construction of five hydroelectric 146 reservoirs, which had strong impacts on the estuary. Decreased precipitations combined to an 147 increased evaporation due to the presence of dams on the watershed have reduced the average 148 annual freshwater discharge from about 2,895 $\mathrm{m}^{3} \mathrm{~s}^{-1}(1961-1990)$ to about 1,800 $\mathrm{m}^{3} \mathrm{~s}^{-1}$ (after Xingó 149 Dam) in 1995 and to less than $1000 \mathrm{~m}^{3} \mathrm{~s}^{-1}$ during the last decade (Bernardes et al., 2012; 150 Cavalcante et al., 2017; de Jong et al., 2018). Floods that strongly influenced the estuarine 151 morphology were suppressed, and most of the riverine suspended sediments, nitrogen, 152 phosphorus and silica were retained in reservoirs, turning the estuary oligotrophic, with chlorophyll 153 concentrations lower than $3 \mu \mathrm{g} \mathrm{L}^{-1}$ in more than $95 \%$ of the samples from recent years (Medeiros 154 et al., 2011; 2018; Melo et al., 2020; Melo-Magalhães et al. 2015). Today, the estuarine morphology consists in a stratified, salt-wedge type, main channel, separated from the sea by a shallow area of submerged dynamic sandy banks, and a secondary channel in the South, 
surrounded by mangroves that have been partly deforested for shrimp farming. Water depth in the main channel in on average $3 \mathrm{~m}$, with a maximum of $12 \mathrm{~m}$ and very shallow depth at the mouth, where sandy banks separate the estuary from the shelf. Strong saline stratification occurs in the main channel and tidal movements generate large variations in surface water salinity and extension of the plume on the shelf (Cavalcantes et al. 2020). Residence time of freshwater in the inner estuary with the surface area of $19 \mathrm{~km}^{2}$ is about half a day (Cavalcante et al. 2017). About $5 \%$ of the freshwater transits through the secondary channel and ends-up in a shallow coastal lagoon parallel to the coast and connected to the sea at high tide through several narrow canals (Fig.1).

\subsection{Fieldwork, chemical analyses and calculations}

Sampling occurred in late winter the $5-8^{\text {th }}$ of August 2014 and in early summer the $11-14^{\text {th }}$ of November 2015, when river discharges were, respectively, 1220 and $950 \mathrm{~m}^{3} \mathrm{~s}^{-1}$, and the tidal ranges were $1.2 \mathrm{~m}$ (end of neap tides) and $1.8 \mathrm{~m}$ (spring tides). Detailed descriptions of all methods for in-situ measurements, discrete water sampling and preservation can be found in Cotovicz et al., (2015) and Cotovicz et al., (2020). Field work consisted in measurement every minute of $\mathrm{pCO}_{2}$ salinity and temperature, and sampling of surface water from freshwater to coastal waters (Salinity $>30$ ) in both channels. Discrete samples were taken along the salinity gradient in the two channels at approximately two-salinity intervals, except in the salinity range 10-25, where changes were too abrupt to allow sampling at regular salinity intervals. Three end-members could be sampled (Fig. 1): the centre of the river main channel, the mouth of the main channel (salinity 30 ), and a shallow coastal lagoon at the outlet of the secondary mangrove channel (Salinity 3034). The $11-12^{\text {th }}$ of Nov. 2015, measurements were also performed during $25 \mathrm{~h}$ at an anchored station in the main channel, were salinity varied from 1.2 at low tide to 32.2 at high tide. Continuous measurements were performed during the vessel's travels or at the anchored station, by pumping surface water at $8 \mathrm{~L} \min ^{-1}$ to a $1 \mathrm{~L}$ vial containing the sondes and a marble-type equilibrator (Frankignoulle et al., 2001). The marble equilibrator consisted in an acrylic tube filled with glass marbles where water flows from the top, and a closed air circuit with a flux of about $(1 \mathrm{~L}$ $\mathrm{min}^{-1}$ ), flowing in the opposite direction from the bottom to the top. The air is dried with drierite and pumped to a non-dispersive infrared (NDIR) gas analyser (LICOR@ LI- 820). Before and after each 
sampling campaigns, the NDIR was calibrated using gas standards with air $p \mathrm{CO}_{2}$ values of 410 , 1007 and 5035 ppmv (White Martins Certified Material, RJ, Brazil). Fresh soda lime was used to set the zero and the standard at 1007 ppmv to set the span. The air standards of 410 and 5035 ppmv were used to verify the linearity of the response. The accuracy of the $p \mathrm{CO}_{2}$ measurements is estimated at \pm 5 ppmv. Water was continuously overflowing from the $1 \mathrm{~L}$ vial that hosted a YSIC Professional Plus multiparameter sonde that measured Temperature, salinity and dissolved oxygen (DO) , and a WTW@ $3310 \mathrm{pH}$ meter equipped with a Sentix 41 electrode. The pH meter was calibrated daily with a three-point standard $(\mathrm{pH} 4.01, \mathrm{pH} 7.00$ and $\mathrm{pH} 10.01)$ according to the National Institute of Standards and Technology (NIST). The precision of the $\mathrm{pH}$ measurements estimated after seven verifications against standards was about 0.01 NBS units. The salinity probe was calibrated before the cruise with IAPSO standard seawater and deionized water. DO was measured with a polarographic electrode calibrated every morning at $100 \%$ saturation in vaporsaturated air. Temperature values measured with the YSIC salinity probe differed from those measured with the WTWC pH-meter by less than $0.1^{\circ} \mathrm{C}$. For continuous measurement performed during sailing, the ship speed was adapted according to the salinity changes and varied between Total alkalinity (TA) was titrated on the discrete samples with certified $0.1 \mathrm{~N} \mathrm{HCl}$ on duplicate $50 \mathrm{~mL}$ $0.7 \mu \mathrm{m}$-filtered samples, using the Gran function to determine the equivalent point.

The concentration of DIC carbonate system was calculated in the discrete samples from the measured $\mathrm{pCO}_{2}$ and TA, with the CO2sys program (Pierrot et al. 2006) using the $\mathrm{CO}_{2}$ solubility from Weiss (1974) and the dissociation constants of Mehrbach et al. (1973), refitted by Dickson and Millero (1987). One important precaution for the use of this set of constants is to check for the absence of organic alkalinity at significant concentrations compared to carbonate alkalinity, particularly in the freshwaters (Cai et al., 1998; Hunt et al., 2011; Abril et al., 2015). In order to identify an eventual bias induced by the interference of organic alkalinity in the calculations of DIC, we used our $\mathrm{pH}$ measurements concomitant to TA measurements in order to calculate $p \mathrm{CO}_{2}$ $(\mathrm{pH} / \mathrm{TA})$ in our discrete samples. The $\mathrm{pCO}_{2}$ values calculated from $\mathrm{pH}$ and $\mathrm{TA}$ and those measured directly with the equilibrator were fairly consistent $(< \pm 10 \%)$, except in a freshwater small tributary on the left edge of the São Francisco River (North of Fig.1 and Fig. S1) that drains a small wetland, 
215 and where the calculated $p \mathrm{CO}_{2}(\mathrm{pH} / \mathrm{TA})$ was more than 4 times higher than the measured $p \mathrm{CO}_{2}$

216 (Cotovicz et al. 2016). However, this tributary does not contribute significantly to the river

217 discharge, as confirmed by our conductivity monitoring at the confluence, and organic alkalinity

218 does not appear to significantly interfere in the calculation of the carbonate system in the São

219 Francisco main channel and mangrove channel.

221 In this work, we analyse and compare the distribution along the salinity gradient of four types of $222 p \mathrm{CO}_{2}$ : the $p \mathrm{CO}_{2}$ observed in situ, noted O-pCO , the $p \mathrm{CO}_{2}$ resulting from conservative mixing of 223 river water with seawater, noted $\mathrm{C}-p \mathrm{CO}_{2}$, the $p \mathrm{CO}_{2}$ normalized to temperature, noted T- $p \mathrm{CO}_{2}$, and 224 the $p \mathrm{CO}_{2}$ resulting from conservative after being corrected for gas exchange, noted Ex-pCO 2 . For 225 each campaign we established the equations of the conservative mixing lines for TA, DIC and 226 temperature as a function of salinity, using the values at the two end-members: the reference 227 freshwater station at the centre of the main channel upstream and the most saline sample at the 228 mouth downstream (Fig. 1). Then the $\mathrm{C}-\mathrm{pCO}_{2}$ thermodynamic conservative mixing curves were 229 calculated for each salinity value where continuous measurements were performed, using the 230 calculated conservative (linear) values of temperature, TA and DIC between the two end-members 231 in the main channel. We evaluated the impact of water heating on $p \mathrm{CO}_{2}$ in the main channel and in 232 the secondary channel passing through the mangrove, by normalizing the $\mathrm{O}-p \mathrm{CO}_{2}$ observed at a 233 given salinity at the temperature corresponding to the linear interpolation of the temperatures in the 234 freshwater and marine end-members. To that end, we calculated for each salinity point 235 measurement, a temperature-normalized $T-p \mathrm{CO}_{2}$ from the measured $p \mathrm{CO}_{2}$ the conservative TA 236 mixing line, and the lowest temperatures observed at each end-member, generally at night and 237 early morning. In winter and neap tides (Aug. 2014), two distinct temperature marine end-members 238 should be considered: one at the mouth of the main channel and another one in the coastal lagoon 239 at the mouth of the mangrove channel (Fig. 1). In contrast, a single set of freshwater and seawater 240 temperature end-members could be used during summer and spring tides (Nov. 2015) when 241 consistent cooler night-time waters were observed in both marine end-members (see results 242 section). 
The evasion or invasion of $\mathrm{CO}_{2}$ at the water-air interface was calculated according to:

where $\mathrm{FCO}_{2}$ is the water-air $\mathrm{CO}_{2}$ flux $\left(\mathrm{mol} \mathrm{m}^{-2} \mathrm{~h}^{-1}\right), \mathrm{k}$ is the gas transfer velocity $\left(\mathrm{m} \mathrm{h}^{-1}\right), \alpha$ is the solubility coefficient $\left(\mathrm{mol} \mathrm{m}^{-3} \mathrm{~atm}^{-1}\right.$ ) and $\Delta \mathrm{pCO}_{2}$ is the difference between water and air $p \mathrm{CO}_{2}$ (in atm). Atmospheric $\mathrm{pCO}_{2}$ was measured every morning and evening by pumping with the NDIR gas analyser and daily average values were used for the flux calculation. To calculate k, we apply three equations as a function of the concomitant wind speed at 10 meters (U10) recorded at a station located 4km landward (Fig.1). The equations of Wanninkhof 1992 (noted W92) and Raymond and Cole (2001) (noted RC01) provide the gas transfer velocity as a function of $\mathrm{U} 10$, and the equation of Abril et al. (2009) (noted A09) as a function of U10, estuarine surface area and water current velocity. In the A09 model, we used a surface area of $19 \mathrm{~km}^{2}$, and an average water current of 0.4 $\mathrm{m} \mathrm{s}^{-1}$ as representative for the São Francisco main channel (Cavalcante et al., 2017). For all calculations, $\mathrm{pCO}_{2}$ and wind speed data were selected in order to calculate $\mathrm{FCO}_{2}$ in winter and

To complete our study, we corrected the theoretical $\mathrm{C}-\mathrm{pCO} \mathrm{CO}_{2}$ conservative mixing curves for the airwater $\mathrm{CO}_{2}$ exchange, building Ex- $p \mathrm{CO}_{2}$ curves. We applied an iterative calculation every salinity unit from 0 to 34 , of the loss or gain of DIC as $\mathrm{CO}_{2}$ evasion or invasion during the mixing of water at salinity $s$ with seawater to reach the value of salinity $s+1$. summer at daytime and in summer at night-time.

where $\mathrm{FCO}_{2}(\mathrm{~s})$ is the flux $\left(\mathrm{mol} \mathrm{m} \mathrm{m}^{-2} \mathrm{~h}^{-1}\right), \mathrm{RT}$ is the residence time $(\mathrm{h})$ and $\mathrm{H}$ is the water depth $(\mathrm{m})$. $\mathrm{FCO}_{2}(\mathrm{~s})$ is calculated with Eq.1 and the $\mathrm{C}-p \mathrm{CO}_{2}$ value at salinity $\mathrm{s}$, deduced from the mixing of DIC(s) with DIC(34) and TA(s) with TA(34). Then, the new corrected DIC concentration at s+1, $\mathrm{DIC}(\mathrm{s}+1)$, is obtained by adding the DICgain(s) to the DIC(s):

$$
\text { Corrected DIC }(s+1)=D I C(s+1)+D I C g a i n(s)
$$

At that step, we recalculate a corrected $C-p \mathrm{CO}_{2}(\mathrm{~s}+1)$ from new mixing between corrected $\mathrm{DIC}(\mathrm{s}+1)$ and $\mathrm{DIC}(34)$, and $\mathrm{TA}(\mathrm{s}+1)$ and $\mathrm{TA}(34)$. The next iteration consisted in calculating the $\mathrm{FCO}_{2}(\mathrm{~s}+1)$ from the corrected C- $p \mathrm{CO}_{2}(\mathrm{~s}+1)$ and the DICgain(s+2) using Eq.1. The model was set-up in the 
CO2sys spreadsheet (Pierrot et al. 2006), each line representing a salinity increment of one unit,

273 from zero to 34 , with the possibility to choose the gas transfer equation, the $U 10, R T$ and $H$.

274 Incrementation of the model allowed the building of thermodynamic Ex- $p \mathrm{CO}_{2}$ mixing curves

275 corrected from gas exchange according to various combinations of these parameters. We used an

$276 \mathrm{RT} / \mathrm{H}$ ratio of 0.17 day $\mathrm{m}^{-1}$ which corresponds to a short $\mathrm{RT}$ value in the São Francisco estuary of

2770.5 day as estimated from the discharge during the cruise, a mean $\mathrm{H}$ of $3 \mathrm{~m}$ and an estuarine

278 surface of $19 \mathrm{~km}^{2}$. In order to simulate conditions closer to the ones occurring in large river plumes,

279 we also tested the influence of increasing $\mathrm{RT} / \mathrm{H}$ to 0.33 and 0.5 day $^{-1}$, and we applied three

280 different wind speeds of $0.5,3$ and $7 \mathrm{~m} \mathrm{~s}^{-1}$, as representative of estuarine and shelf meteorological

281 conditions. In addition, we assumed that the residence time was uniformly distributed along the

282 salinity gradient, although there might be some exceptions as for instance longer residence times

283 (several tidal cycles) in the low salinity range.

\section{Results}

DIC and TA increased linearly with salinity in the main channel, respectively from $553 \pm 40$ and $539 \pm 27 \mu \mathrm{mol} \mathrm{kg}^{-1}$ in the river end-member to $1719 \pm 127$ and $1975 \pm 146 \mu \mathrm{mol} \mathrm{kg}{ }^{-1}$ at the mouth with salinity $>30$ (Fig. 2). Some significant positive anomalies of both parameters were observed at high salinity stations in the mangrove channel (Fig. 2). During both cruises, $\mathrm{O}-p \mathrm{CO}_{2}$ was highly variable

290 in the freshwater with some lateral heterogeneity between the different channels, and was above

291 the atmospheric $p \mathrm{CO}_{2}$ at the centre of the main channel, with a value of $\sim 700 \mathrm{ppmv}$ (Fig.3A\&B).

292 Downstream in the main channel, O- $\mathrm{pCO}_{2}$ sharply decreased below $400 \mathrm{ppmv}$ at salinity 3, and

293 followed an asymmetric bell-shaped curve along the salinity gradient. In winter, O- $p \mathrm{CO}_{2}$ distribution 294 in the main channel was almost perfectly predicted by thermodynamics during mixing with average 295 difference between $\mathrm{O}-\mathrm{pCO}_{2}$ and $\mathrm{C}-\mathrm{pCO}_{2}$ in the 3-30 salinity range being $3 \pm 13 \mathrm{ppmv}$ (Table 1 ), that 296 is, within the error of $p \mathrm{CO}_{2}$ measurements and mixing model calculations. In summer, however, O$297 \mathrm{pCO}_{2}$ in the main channel was on average $43 \pm 35 \mathrm{ppmv}$ above the theoretical mixing curve of $\mathrm{C}$ $298 \quad \mathrm{CCO}_{2}$ along the 3-30 salinity range at night-time and daytime. Measured $\mathrm{O}-\mathrm{pCO} \mathrm{O}_{2}$ included under299 saturated values and invasion of atmospheric $\mathrm{CO}_{2}$ at salinities above 3 during both cruises 300 (Fig.3A\&B). The most marine waters with salinities $>30$ were under-saturated in Aug. 2014 (O- 
$\left.p \mathrm{CO}_{2}: 332 \mathrm{ppmv}\right)$ and almost at equilibrium (O-pCO $\mathrm{CO}_{2}: 403 \pm 18$ ppmv) in Nov. 2015 (Fig. 3E\&F). In

the mangrove channel, $\mathrm{O}-\mathrm{pCO}_{2}$ was higher and more variable than in the main channel: between 298 and 975 ppmv (mean 512 ppmv) in winter and between 307 and 2007 ppmv (mean 976 ppmv) in summer (Fig. $3 A \& B$ ). Several $\mathrm{O}-\mathrm{pCO}_{2}$ peaks occurred in the mangrove channel and the adjacent coastal lagoon, at intermediate and high salinities and variations also occurred according to the tidal phase, with higher values in Nov. 2015 corresponding to low tide at spring tide period. A maximum of 2000 ppmv was recorded in the coastal lagoon at the outlet of the mangrove channel during the afternoon at low tide (Fig. 3B). During the two cruises DO remained between $99 \%$ and $101 \%$ saturation throughout most of the salinity gradient in the main channel (Fig. S2). At both seasons, significant DO undersaturation occurred in the river at low salinities and in the mangrove 311 channel, with lower minimum values in Nov. 2015 compared to Aug. 2014. In Nov. 2015, slight DO 312 oversaturation ( $\max 103 \%$ ) was observed in the main channel at salinities around 3 and above 31 313 (Fig. S2). Water temperatures were lower in Aug. 2014 than in Nov. 2015 (Fig. 3C.D). During winter and neap tide (Aug. 2014), temperature remained constant in the main channel, and about $1^{\circ} \mathrm{C}$ above the conservative mixing line in the mangrove channel, showing that water heating occurred (Fig. 3C). In Aug. 2014, O-p $\mathrm{CO}_{2}$ was higher than the $\mathrm{T}-\mathrm{pCO}_{2}$ by 5-20ppmv in the mangrove channel, 319 but less than 2ppmv in the main channel (Fig. 3E). In Nov. 2015, when measurements were also 320 performed at night, surface heating was evident from night-time to daytime, as well as, within the mixing zone in comparison with the two end-members. The entire salinity gradient in both channels was more than $1^{\circ} \mathrm{C}$ cooler at night and early morning (before $9 \mathrm{~h}$ ) than at daytime and dusk (Fig. 3D), which resulted in $\mathrm{O}-\mathrm{pCO} 2$ higher than the $\mathrm{T}-\mathrm{pCO}_{2}$ by $10-15 \mathrm{ppmv}$ (Fig. 3F). A peak temperature of $29.8^{\circ} \mathrm{C}$ occurred in Nov. 2015 during the afternoon in the shallow lagoon at the outlet of the mangrove channel at low tide, which corresponded to a O- $p \mathrm{CO}_{2} 120 \mathrm{ppmv}$ higher than T-pCO 2 , when the O- $p \mathrm{CO}_{2}$ reached 2000 ppmv (Fig. 3F). 
salinities and $476 p p m v$ at low salinity. The record at one minute frequency revealed a remarkable

331 parallelism between $\mathrm{O}-\mathrm{pCO} \mathrm{O}_{2}$ and $\mathrm{C}-\mathrm{pCO}_{2}$ calculated from the mixing of the two end-members and

332 the salinity value. However, $\mathrm{O}-\mathrm{pCO}_{2}$ was on average $+43 \pm 35 p p m v$ above the conservative mixing 333 curve o C- $p \mathrm{CO}_{2}$ (Fig. 4). Maximum deviations of $\mathrm{O}-p \mathrm{CO}_{2}$ from $\mathrm{C}-\mathrm{pCO}_{2}$ occurred during the ebb 334 tides, both at sunset and night (hours 1.5 to $4.2: 52 \pm 19 p p m v$ ) and at sunrise and early morning 335 (hours 13.5 to 17.5: $92 \pm 30 p p m v$ ). In addition, at low tide when salinities were below 3, O- $p \mathrm{CO}_{2}$ 336 values were close to the $\mathrm{C}-\mathrm{pCO}_{2}$ at daytime (hours 19-21.5), but were $\sim 60 \mathrm{ppmv}$ higher than $\mathrm{C}$ $337 \mathrm{pCO}_{2}$ at night-time (hours 7-10) indicating diurnal variations in this low salinity range (Fig. 3). 338 Finally, throughout the $25 \mathrm{~h}$ cycle, some heating effect on $\mathrm{pCO}_{2}$ was detected during the afternoon 339 at high tide and high salinity (hours 1 and 25) and at low tide and low salinity (hour 20), when O$340 \quad p \mathrm{CO}_{2}$ was at maximum $+25 p p m v$ higher than $\mathrm{T}-p \mathrm{CO}_{2}$ (Fig. 4B).

342 Wind speed was low during the cruises, always below $3.5 \mathrm{~m} \mathrm{~s}^{-1}$, on average between $1.1 \mathrm{~m} \mathrm{~s}^{-1}$ in 343 Nov. 2015 and $2.2 \mathrm{~m} \mathrm{~s}^{-1}$ in April at day time, and $0.5 \mathrm{~m} \mathrm{~s}^{-1}$ at night-time (Table 1). In the main 344 channel, $\mathrm{FCO}_{2}$ fluxes varied between 0.01 and $0.79 \mathrm{mmol} \mathrm{m}^{-2} \mathrm{~h}^{-1}$ (positive fluxes for $\mathrm{CO}_{2}$ evasion) 345 in the 0-3 salinity range and between -0.04 and $-1.68 \mathrm{mmol} \mathrm{m}^{-2} \mathrm{~h}^{-2}$ in the 3-30 salinity range. In the 346 mangrove channel, calculated $\mathrm{FCO}_{2}$ varied between 1.23 and $10.72 \mathrm{mmol} \mathrm{m}^{-2} \mathrm{~h}^{-1}$. For the 347 observed wind speed range, calculated $\mathrm{FCO}_{2}$ strongly depended on the choice of the $\mathrm{k}_{600}$ 348 parameterization, the W92 equation giving lower fluxes than the RC01 and A09 equations (Table 349 1).

351 Ex- $p \mathrm{CO}_{2}$, the theoretical thermodynamic $p \mathrm{CO}_{2}$ mixing curves corrected for gas exchange, were 352 below the standard conservative curve between salinities 0 and 3-5, where $\mathrm{CO}_{2}$ evasion occurs, 353 and above the curve between salinities 3-5 and 34, where invasion of atmospheric $\mathrm{CO}_{2}$ occurs 354 (Fig. 5). Computed deviation from conservative mixing, i.e. Ex- $p \mathrm{CO}_{2}$ minus $\mathrm{C}-p \mathrm{CO}_{2}$ strongly 355 depended on the selected parameters, the gas transfer parametrization, the U10 and the 356 residence time / depth ratio. These deviations varied from -0.3 to $-167 \mathrm{ppmv}$ (average $-29 \mathrm{ppmv}$ ) in 357 the $0-3$ salinity range and from -8 to $+76 \mathrm{ppmv}$ (average $+16 \mathrm{ppmv}$ ) in the $3-30$ salinity range. 358 Applying a residence time in the São Francisco estuary of 0.5 days during the cruises, an average 
water depth of $3 \mathrm{~m}$ and the $\mathrm{U} 10$ values of 0.5 and $3 \mathrm{~m} \mathrm{~s}^{-1}$ as representative for the conditions during the cruise, gives $\mathrm{Ex}-p \mathrm{CO}_{2}-\mathrm{C}-\mathrm{pCO}$ values of $-12 \pm 9 p p m v$ in the $0-3$ salinity range and $4 \pm 3 p p m v$ in the 3-30 salinity range (Table 1 ).

\section{Discussion}

\subsection{Predominance of thermodynamics}

In the main channel, the $p \mathrm{CO}_{2}$ measurements $\left(\mathrm{O}-p \mathrm{CO}_{2}\right)$ and the thermodynamic estuarine conservative mixing model $\left(\mathrm{C}-p \mathrm{CO}_{2}\right)$ follow the same asymmetric bell-shape curve, with a steep decrease from salinity zero to 3 , and undersaturation of surface waters all along the 3-30 salinity gradient (Fig. 3). To date, such well-defined $p \mathrm{CO}_{2}$ curve, with high resolution measured values very consistent with the theoretical conservative mixing curve, have been reported in the Amazon plume only for salinities higher than 17 , and in the tropical Paraiba do Sul along the entire salinity gradient, with continuous $p \mathrm{CO}_{2}$ measurements (Cotovicz et al., 2020). In the mesotrophic Paraiba do Sul River Estuary, autotrophic and heterotrophic activities had strong influences on the $\mathrm{pCO}_{2}$ distribution along the salinity gradient at low river discharge, but not at high discharge and shorter residence time, when the $p \mathrm{CO}_{2}$ versus salinity plot followed the theoretical curve (Cotovicz et al. 2020). Because of the oligotrophic character of the São Francisco estuary (Medeiros et al. 2011; 2018) and the short residence time of water in the mixing zone (half a day), thermodynamics predominates over biological processes in controlling estuarine $p \mathrm{CO}_{2}$ distribution along the estuarine gradient. Some theoretical works have described how thermodynamics during estuarine mixing can generate positive or negative air-water $\mathrm{CO}_{2}$ fluxes depending on the DIC and TA concentrations in the river end-member, the concentrations in the marine end-member being considered as constant in comparison (Whitfield and Turner, 1986; Cai et al., 2013; Delaigue et al. 2020). In the case of the São Francisco with a low TA river end-member (around $500 \mu \mathrm{mol} \mathrm{kg}{ }^{-1}$ ), and warm waters (above $25^{\circ} \mathrm{C}$ ), thermodynamics during mixing turns the estuary into a sink of atmospheric $\mathrm{CO}_{2}$ (Whitfield and Turner, 1986); this is also the same for the Amazon (TA of 450 $\left.\mu \mathrm{mol} \mathrm{kg}{ }^{-1}\right)$ and the Congo $\left(300 \mu \mathrm{mol} \mathrm{kg}{ }^{-1}\right)$ but not the Mississippi $\left(>2000 \mu \mathrm{mol} \mathrm{kg}{ }^{-1}\right)$, where carbonate thermodynamics generates a $\mathrm{CO}_{2}$ source and where the observed $\mathrm{CO}_{2}$ invasion is 
biological as revealed by nitrate uptake (Cai et al., 2013). Although the conditions found in the largest world rivers potentially generate a $\mathrm{CO}_{2}$ sink in the coastal zone, very few in-situ $\mathrm{pCO}_{2}$ data cover a complete estuarine salinity gradient consistent with the $\mathrm{pCO}_{2}$ theoretical mixing curve (Cai et al. 2013; Lefèvre et al. 2017; Cotovicz et al. 2020). In winter in the São Francisco estuary, the average difference between $\mathrm{O}-p \mathrm{CO}_{2}$ and $\mathrm{C}-\mathrm{pCO}_{2}$ was only $3 \pm 13$ ppmv along the 3-30 salinity range in the main channel and thermodynamics was apparently the unique driver of the carbonate system, creating a permanent $\mathrm{CO}_{2}$ influx in this salinity range. In summer, the average difference between $\mathrm{O}-p \mathrm{CO}_{2}$ and $\mathrm{C}-p \mathrm{CO}_{2}$ at salinities $>3$ was $+49 \pm 39$ ppmv at daytime and $+36 \pm 22$ at nighttime (Table 1), but $\mathrm{O}-\mathrm{pCO}_{2}$ always remained below the atmospheric value of $400 \mathrm{ppmv}$ at salinities above 3 , and thermodynamic uptake of atmospheric $\mathrm{CO}_{2}$ was predominant.

Our continuous measurements in the São Francisco also allow an interpretation of these O-pCO 2 deviations from $\mathrm{C}-\mathrm{pCO} \mathrm{CO}_{2}$ as the result of other internal $\mathrm{CO}_{2}$ sources and sinks. First, estuarine NEP and lateral transport from river and intertidal areas can be a source of $\mathrm{CO}_{2}$ (Abril and Borges, 2011; Bauer et al., 2013). Second, $C-p \mathrm{CO}_{2}$ simulations were based on the conservative mixing of temperature at daytime at the two end-members, although heating and cooling of water is a common feature in this semi-arid region, and can potentially change $\mathrm{pCO}_{2}$ at daily and tidal time scales, particularly in shallow regions of the estuary such as the lagoon. Third, while air-water exchange of $\mathrm{CO}_{2}$ is much slower than acid-base equilibration of DIC species, evasion and invasion of $\mathrm{CO}_{2}$ occur during estuarine mixing, potentially altering the thermodynamic $\mathrm{pCO}_{2}$ curve. All these processes can generate $p \mathrm{CO}_{2}$ changes of few tens of ppmv that can add up to the values of $p \mathrm{CO}_{2}$ deviations from the mixing curves in summer (Cotovicz et al., 2020). However, when interpreting these deviations, we must also keep in mind that the shape of the modelled $\mathrm{C}-\mathrm{pCO} \mathrm{O}_{2}$ curve depends on the choice of the freshwater end-member, which was difficult to define because of lateral heterogeneity. For example, we calculated that using a freshwater end-member with $5 \mu \mathrm{mol}$ $\mathrm{kg}^{-1}$ higher TA (or DIC) (a change within the range of analytical precision for these parameters), generates mixing $\mathrm{pCO}_{2}$ values 10 ppmv lower (or 9 ppmv higher) at salinity 10 . In the case of our study, we choose to use the TA and $\mathrm{pCO}_{2}$ values at the central and deepest station upstream all the small islands (Fig. 1), where most freshwater flows and with little tidal influence, and not an 
417 average of all measurements at the lowest salinity $(<0.1)$ region. Owing to the significant

418 heterogeneity in the different canals, we cannot totally exclude lateral input of freshwater from

419 small tributaries in this region that alter the DIC concentrations in the end-member and the 420 modelled mixing $p \mathrm{CO}_{2}$ curve.

\subsection{Biological $\mathrm{CO}_{2}$ sources and sinks}

423 The diurnal O- $\mathrm{CCO}_{2}$ change at low salinity (Fig. 4) reveals some photosynthetic activity in this 424 region, despite the chlorophyll concentration around $3 \mu \mathrm{L} \mathrm{L}^{-1}$ (unpublished data). During our measurements (Fig. 4), the respiration of this plankton apparently generated a deviation of +60 ppmv above the conservative mixing at night-time and early morning (hours $7-9$ ), compared to the afternoon when phytoplankton absorbed $\mathrm{CO}_{2}$ (hours 21-23). Concomitant change in DO could be detected, although the DO values remained very close to $100 \%$ at night time and daytime in the whole salinity range. We calculated that, for the conditions of Nov. 2015, the diurnal change of 60

430 ppmv of $\mathrm{O}-\mathrm{pCO}_{2}$ at salinity 3 corresponds to a change in DIC of $5 \mu \mathrm{mol} \mathrm{kg}{ }^{-1}$. If we assume a 431 photosynthetic/respiratory quotient of 1 , the equivalent diurnal change in DO in these oligotrophic 432 waters would be about $2 \%$ sat. In fact, in Nov. 2015, the DO concentration at salinity 3 was $100 \%$ 433 at night time and $103 \%$ at daytime (Fig. S2), but these differences remained close to the error in 434 DO measurements. Consequently, $\mathrm{pCO}_{2}$ monitoring was much more powerful than $\mathrm{O}_{2}$ monitoring 435 to detect photosynthetic activity in the oligotrophic São Francisco estuary. It is well known that 436 freshwater phytoplankton can still be active in estuaries at low salinities, but generally not at higher 437 salinities in the mixing zone, where they die due to saline stress (Lancelot and Muylaert, 2012). 438 This is probably the case in the São Francisco estuary, where, despite the general low biomass, 439 freshwater phytoplankton potentially fuels heterotrophy downstream in the main channel. However, 440 the residence time of half a day is probably too short to allow the well establishment of an active 441 heterotrophic community (Crump et al., 2004). Benthic heterotrophy is probably limited in the 442 sandy sediments of the São Francisco estuary where strong hydrodynamics limits the deposition of 443 fine organic biodegradable material (Medeiros et al. 2007). Along the salinity gradient, the 444 deviation of $\mathrm{O}-\mathrm{pCO}_{2}$ from $\mathrm{C}-\mathrm{pCO} \mathrm{CO}_{2}$ was spatially and temporally linked to tidal advection from 445 mangroves and other brackish marshes. Many authors have reported high $\mathrm{CO}_{2}$ degassing fluxes 
from mangrove surrounding waters (Borges et al., 2003; Maher et al., 2013; Santos et al., 2018;

Cotovicz et al., 2020). High water $p \mathrm{CO}_{2}$ come from the tidal pumping of mangrove-saturated soil

$\mathrm{CO}_{2}$ (Maher et al., 2013; Santos et al., 2018), and from the respiration of mangrove-derived organic matter in creek waters and sediments (Bouillon et al., 2003; Borges and Abril, 2011). In the mangrove's soils, a large part of the metabolism is sulphate reduction that stoichiometrically produces the same amount of TA than $\mathrm{CO}_{2}$ (Borges et al., 2003). This explains the positive TA 452 (and associated DIC) anomalies observed at high salinities in the mangrove channel of the São 453 Francisco Estuary (Fig. 2). Although water $\mathrm{O}-\mathrm{pCO} \mathrm{CO}_{2}$ was similar during both campaigns in the main 454 channel, in the secondary channel, $\mathrm{pCO}_{2}$ values were much higher, particularly in Nov. 2015 compared to Aug. 2014. This can be attributed to the spring tide conditions during sampling in 456 2015, enhancing the tidal pumping (Maher et al., 2013; Santos et al., 2018). During the 25h cycle 457 in the main channel at spring tide in 2015 (Fig.4), the highest (>100 ppmv) and longest positive 458 deviations of $\mathrm{O}-p \mathrm{CO}_{2}$ from $\mathrm{C}-p \mathrm{CO}_{2}$ occurred during the ebb tides, particularly at late night and 459 early morning (hours 14-17) which reveals an export from the mangrove waters to the main 460 channel that affects the 5-8 salinity range (Fig.3B). The monitoring point during $25 \mathrm{~h}$ was located at 461 less than two km from confluence between the main channel and the mangrove channel, and also 462 close to brackish tidal marshes (Fig.1) that could contribute, together with mangroves to the $\mathrm{pCO}_{2}$ 463 peaks at high and ebb tide. In addition, the short residence time of waters in the estuary suggests 464 that heterotrophs would spend little time in the main channel and would be exposed to strong 465 salinity stress to generate significant respiratory $\mathrm{CO}_{2}$, which is apparently coming in majority from 466 tidal pumping.

\subsection{Impact of heating}

469 Semi-arid coastal ecosystems are environments where heating and evaporation can have a strong 470 influence on the water chemistry and where very few studies document the behaviour of the 471 carbonate system (Leopold et al., 2016; Yao and Hu, 2018; Yao et al., 2020). Heating of water will 472 first increase the $\mathrm{pCO}_{2}$ and favour outgassing (Takahashi et al., 2002). If evaporation is intense 473 and leads to hypersaline conditions, consumption of TA and release of $\mathrm{CO}_{2}$ due to carbonate precipitation can occur (Murgulet et al., 2018; Yao et al., 2020). In the São Francisco estuary, 
475 higher temperature relative to the mixing of the two end-members was most pronounced during 476 summer and in the mangrove secondary channel (Fig. 3C.D). In summer, despite the short 477 residence time of waters, the temperature increased in both channels by more than $1^{\circ} \mathrm{C}$ during 478 daytime compared to night-time (Fig. 3D), which corresponds to a theoretical $p \mathrm{CO}_{2}$ increase 479 (difference between $\mathrm{O}-\mathrm{pCO}_{2}$ and $\mathrm{T}-\mathrm{pCO}_{2}$ ) of $\sim 15 \mathrm{ppmv}$ (Fig. 3F). In the main channel, the 25h 480 cycle (Fig.4) reveals that heating at daytime has a significant impact on $p \mathrm{CO}_{2}$ at both low tide (hour 48121 ) and high tide (hours 1 and 25). In Nov. 2015 at salinities $>3$, averaged observed $p \mathrm{CO}_{2}$ in the 482 main channel in summer were 33ppmv higher during daytime than during night-time, and the 483 thermal effect contributed to $25 \%$ of the deviation of $p \mathrm{CO}_{2}$ above the conservative curve at daytime 484 and $10 \%$ at night, when estuarine waters still remained warmer than predicted from the mixing of 485 the end-members (Table 1 ). At salinities $<3$, the thermal effect was partially offset by biological 486 productivity and the $\mathrm{O}-\mathrm{pCO}_{2}$ were similar at night-time and daytime. However, the daytime data 487 included salinities below 1.4 with higher $\mathrm{O}-\mathrm{pCO}_{2}$, whereas night-time data did not (Table 1). In the 488 secondary channel, the maximal thermal effect occurred at salinity $\sim 28$ in the coastal lagoon in the 489 afternoon at low tide, with an increase in temperature of $\sim 3^{\circ} \mathrm{C}$ concomitant with a maximum $p \mathrm{CO}_{2}$ 490 of $\sim 2000$ ppmv (Fig.3C,F). The thermal effect at this site (Fig.3F) contributed to $15 \%$ of the 491 deviation of $p \mathrm{CO}_{2}$ above the conservative curve at maximum (Fig. $3 \mathrm{~B}$ ), and this $p \mathrm{CO}_{2}$ peak is 492 attributed to the maximum pumping of mangrove-derived $\mathrm{CO}_{2}$ at low tide. Although water depth 493 was less than half a meter and temperature reached $29.8^{\circ} \mathrm{C}$, we found no evidence of carbonate 494 precipitation during this event as those reported in other semi-arid coastal lagoons (Yao et al., 495 2020). Indeed, the salinity was only 28 during the $\mathrm{pCO}_{2}$ peak and increased only when the tide 496 started to enter the system through the small canals (Fig.1); no significant TA consumption could 497 confirm carbonate precipitation, TA was above the mixing line in this region, as a result of tidal pumping of DIC from predominant sulphate reduction and other anaerobic processes in the 499 mangrove soils (Borges et al., 2003; Santos et al., 2018).

\subsection{Impact of gas exchange}

502 The fact that thermodynamic mixing in the main channel generates undersaturated $p \mathrm{CO}_{2}$ 
salinities $>3$. Consequently, the hypothesis of conservative DIC mixing on which the

thermodynamic $p \mathrm{CO}_{2}$ curve relies will become invalid, whereas that of conservative TA will remain valid. If we consider the average and standard deviation air-water $\mathrm{CO}_{2}$ fluxes calculated with the conservative $p \mathrm{CO}_{2}$ mixing curve and the three gas exchange equations (Table 1), then thermodynamic during mixing in the main channel emits $+2.5 \pm 1.7 \mathrm{mmol} \mathrm{m}^{-2} \mathrm{~h}^{-1}$ of $\mathrm{CO}_{2}$ at salinity lower than 3 and absorbs $-1.3 \pm 0.6 \mathrm{mmol} \mathrm{m}^{-2} \mathrm{~h}^{-1}$ of $\mathrm{CO}_{2}$ between salinities 3 and 34 . A precise

510 integration of these fluxes would require an estimate of the relative surface area of different salinity 511 ranges according to the shape of the $\mathrm{pCO}_{2}$ bell curve. In particular, it is necessary to separate the $5120-3$ salinity range that behaves as a source (as does the river) from the estuarine waters with 513 salinities above 3 that behave as a sink (Table 1). During our study, we could sample the marine 514 end-member in the shallow waters of the mouth of the estuary at high tide (Fig. S1). However, at 515 low tide as well as on average over the tidal cycle, salinity at the mouth is generally lower, and a 516 significant part of the salinity gradient occurs in a plume offshore. Based on numerical modelling, 517 Cavalcante et al. (2020) showed that the tide-integrated salinity at the mouth of the São Francisco 518 Estuary can be as low as 22 during concomitant neap tides and high river flow. In addition, surface 519 waters with salinities lower than 34 extends $5-20 \mathrm{~km}$ offshore, with a surface area up to $50 \mathrm{~km}^{2}$, that 520 is, an area much larger than the $19 \mathrm{~km}^{2}$ of the inner estuary (Cavalcante et al. 2020). Considering 521 the low river discharge during the study period, an area of $6 \mathrm{~km}^{2}$ for the $0-3$ salinity range, which 522 corresponds to one third of the inner estuary, emits $4.3 \mathrm{tC}$ per day. An area $30 \mathrm{~km}^{2}\left(13 \mathrm{~km}^{2}\right.$ in the 523 inner estuary and $17 \mathrm{~km}^{2}$ in the plume offshore) for the 3-34 salinity range will absorb $-11.2 \mathrm{tC}$ per 524 day. With these hypotheses on the surface areas, the São Francisco Estuary absorbs 7tC per day 525 of $\mathrm{CO}_{2}$. In comparison, the input of DIC by the river was 95 and 70 tC per day, respectively in Aug. 5262014 and Nov. 2015. Consequently, the invasion of $\mathrm{CO}_{2}$ from the atmosphere due to 527 thermodynamics during mixing will increase the DIC export to the sea by $7-10 \%$. This modest 528 increase in the DIC discharge of the São Francisco Estuary to the ocean might be also partly 529 explained by its morphology and hydrological feature induced by very shallow depths at the mouth 530 and a very steep longitudinal salinity gradient between 10 and 25 inside the lagoon (Fig. 4). 
532 By calculating for each salinity increment the quantity of $\mathrm{CO}_{2}$ absorbed from the atmosphere during

533 the residence time of waters in the estuary, our mixing Ex- $p \mathrm{CO}_{2}$ model provides a precise

534 evaluation of the impact of gas exchange on the $\mathrm{C}-\mathrm{pCO} \mathrm{C}_{2}$ curves (Fig. 5). Evasion occurs first at low 535 salinity, and the correction is negative during a restricted amount of time; invasion occurs at salinity 536 above 3-5 with a positive correction and presumably during a longer amount of time. In the case of 537 the São Francisco Estuary, with a water depth of $3 \mathrm{~m}$, a residence time of half a day and relatively 538 low wind speed values (Table 1), the model results in a difference between $\mathrm{C}-p \mathrm{CO}_{2}$ and Ex- $p \mathrm{CO}_{2}$ 539 of only 4 ppmv in the 3-30 salinity range in Nov. 2015 , corresponding to $\sim 10 \%$ of the $\mathrm{O}-\mathrm{pCO}_{2}$ 540 deviation above the $\mathrm{C}-\mathrm{pCO} \mathrm{CO}_{2}$ mixing curve. However, strong stratification of the water column at 541 intermediate salinities may alter this conclusion in two opposite ways: on one hand, if we consider 542 a mixed surface layer of only $1 \mathrm{~m}$ height as representative in-situ conditions (Cavalcante et al. 543 2017), $\mathrm{CO}_{2}$ invasion will generate a larger difference between $\mathrm{Ex}-p \mathrm{CO}_{2}$ and $\mathrm{C}-\mathrm{pCO}$, on average $544 \sim 12 p p m v$, which corresponds to $\sim 25 \%$ of the $\mathrm{O}-\mathrm{pCO}_{2}$ deviation above the $\mathrm{C}-p \mathrm{CO}_{2}$ mixing curve at 545 salinity > 3 in Nov. 2015; on the other hand, stratification of the water column implies that part of 546 the mixing of estuarine water occurs below the water surface, that is, without contact with the 547 atmosphere and without gas exchange. Wind speed, fetch length, and water current all contribute 548 to surface turbulence in estuaries, where gas exchange is generally faster than in the ocean 549 (Borges et al., 2004; Orton et al., 2010). Most of the proposed k600 parameterization in estuaries 550 are based on data in relatively well-mixed estuaries (Borges et al., 2004; Abril et al., 2009; Orton et 551 al., 2010). To our best knowledge, no gas exchange study has been performed in highly stratified 552 systems, where buoyancy fluxes dissipate kinetic energy as turbulence (Etemad-Shahidi and 553 Imberger, 2002) potentially enhancing gas exchange, whereas stratification limits the vertical 554 diffusion of atmospheric $\mathrm{CO}_{2}$ to the whole water column. In large tropical estuaries and plumes 555 such as the Amazon and the Congo, most of the salinity gradient occurs offshore where wind 556 speed is higher. Gas exchange in these plumes can significantly alter the $\mathrm{C}-\mathrm{pCO} \mathrm{CO}_{2}$ mixing curves 557 and the impact of stronger wind and longer residence time in the mixing zone might be partially 558 offset by a deeper mixed layer in the range of 5-30 m (Grodsky et al., 2014; Phillipson and Toumi, 559 2020). 
4.5. Relative contributions of $p \mathrm{CO}_{2}$ deviations from conservative mixing

In August 2014 in the main channel of the São Francisco estuary, heating and tidal pumping were almost negligible and we found little deviation of $\mathrm{O}-p \mathrm{CO}_{2}$ from $\mathrm{C}-p \mathrm{CO}_{2}$, except in the salinity range $0-3$, where the $\mathrm{O}-p \mathrm{CO}_{2}$ were on average $45 \mathrm{ppmv}$ lower than the modelled conservative $p \mathrm{CO}_{2}$ (Fig. 3A), suggesting the occurrence of autotrophic activity by phytoplankton and/or $\mathrm{CO}_{2}$ evasion in the area, consistent with observations at low tides in Nov. 2015 during the 25h cycle (Fig. 4). In contrast, the deviation from conservative mixing was more pronounced in Nov. 2015, during summer and spring tides, and we could calculate the distribution of the three major active processes that make $\mathrm{pCO}_{2}$ deviate from the conservative curve along the salinity gradient, that is, (i) surface water heating or cooling based on temperature field data $\left(\mathrm{T}-p \mathrm{CO}_{2}\right)$, (ii) evasion or invasion of $\mathrm{CO}_{2}$ based on modelling $\left(\mathrm{Ex}-\mathrm{pCO}_{2}\right)$, and (iii) autotrophy or the sum of heterotrophy and tidal pumping from mangrove creeks as the residual part of the deviation between modelled and observed data, calculated as O- $p \mathrm{CO}_{2}-\mathrm{T}-p \mathrm{CO}_{2}-\mathrm{Ex}-\mathrm{pCO}_{2}$ (Cotovicz et al. 2020). We have binned our Nov. 2015 data, calculating the means and standard deviations of $\mathrm{O}-p \mathrm{CO}_{2}$ and T- $p \mathrm{CO}_{2}$ for each salinity increment. In Aug. 2014, the deviation of $\mathrm{pCO}_{2}$ from conservative mixing was too low (Table 1). The difference between O- $p \mathrm{CO}_{2}, \mathrm{C}-p \mathrm{CO}_{2}, \mathrm{~T}-p \mathrm{CO}_{2}$ and $\mathrm{Ex}-p \mathrm{CO}_{2}$ were within the uncertainties of measurements and calculations, meaning that thermodynamics alone drives almost all the $\mathrm{O}-\mathrm{pCO}_{2}$ distribution. The 2015 binned $\mathrm{O}-\mathrm{pCO} \mathrm{C}_{2}$ and $\mathrm{T}-\mathrm{pCO} \mathrm{O}_{2}$ could be compared with the modelled $\mathrm{C}-p \mathrm{CO}_{2}$ and $\mathrm{Ex}-\mathrm{pCO} \mathrm{CO}_{2}$ (Fig. 6). We also separated the day and night periods for the regions with salinities above and below 3 and we calculated the $\mathrm{CO}_{2}$ fluxes corresponding to these three processes (heating, gas exchange and the residual as biological activity) using wind speed data and three gas transfer parameterizations (Table 2). The calculations indicate that in Nov. 2015 , heating was consistently stronger at daytime compared to night-time, and contributed to a peak at 20 ppmv at salinity 28 (Fig. 6), and a maximum average deviation from conservativity of +12 ppmv at daytime and salinity above 3 , corresponding to a heating $\mathrm{CO}_{2}$ flux of $0.2 \mathrm{mmol} \mathrm{m}^{-2} \mathrm{~h}^{-1}$ (Table 2). Gas exchange had a slightly lower impact on $p \mathrm{CO}_{2}$ values than heating, with rapid evasion of river-borne $\mathrm{CO}_{2}$ occurring at low salinity and $\mathrm{CO}_{2}$ invasion at salinity between 3 and 34 . According to our quantitative analysis, concomitant $\mathrm{CO}_{2}$ evasion and net autotrophy occur in the 03 salinity range, whereas concomitant $\mathrm{CO}_{2}$ invasion and net heterotrophy associated to tidal 
pumping from mangroves occur at salinity above 3 (Fig. 6). This trend in the São Francisco

591 Estuary is similar to the one recently reported in the mesotrophic Paraiba do Sul Estuary during high river discharge (Cotovicz et al. 2020). These two river-dominated tropical estuaries have low

593 TA concentrations in the river end-member. At low salinities, inputs of river-borne $\mathrm{CO}_{2}$ combined 594 with low buffering capacity favour outgassing, whereas little salinity stress allows some production 595 of freshwater phytoplankton (Cloern, 1996; Lancelot and Muylaert, 2012; Cotovicz et al., 2020). At 596 salinities below 3 , the $\mathrm{O}-p \mathrm{CO}_{2}$ values were $109 \mathrm{ppmv}$ below the modelled $\mathrm{C}-p \mathrm{CO}_{2}$ values at 597 daytime, but 34 ppmv above at night-time (Table 2), consistent with phytoplanktonic photosynthetic 598 activity. The different salinity ranges sampled at daytime (0-3) and night-time (1.4-3) do not allow 599 to accurately estimate a NEP from diurnal variations in the upper estuary. At increasing salinities, 600 the mixing with buffered seawater creates thermodynamics conditions for $\mathrm{CO}_{2}$ invasion and offsets 601 some apparent heterotrophy combined with tidal advection of mangrove-derived $\mathrm{CO}_{2}$. The latter 602 generates a deviation (calculated as O- $p \mathrm{CO}_{2}-\mathrm{T}-p \mathrm{CO}_{2}-\mathrm{Ex}-p \mathrm{CO}_{2}$ ) of about $40 \mathrm{ppmv}$ of $p \mathrm{CO}_{2}$ 603 along the 4-25 salinity range (Fig. 6) and +33 ppmv (daytime) and +27 ppmv (night time) on 604 average over the 3-34 salinity gradient (Table 2). Interestingly, our approach also suggests some autotrophic activity in the $30-33$ salinity range (Fig. 6B), which is also a classical pattern of phytoplankton distribution in estuaries; indeed, blooms of marine phytoplanktonic species are a common feature in high salinities regions of river plumes, where they can take benefit from the available light and nutrients and from the stratification of the water column (Cloern, 1996; Lancelot and Muylaert, 2012). Heating of water made $\mathrm{O}-p \mathrm{CO}_{2}$ higher than $\mathrm{T}-p \mathrm{CO}_{2}$ all along the salinity gradient with a maximum difference between $\mathrm{O}-\mathrm{pCO}_{2}$ and $\mathrm{T}-\mathrm{pCO} \mathrm{O}_{2}$ of $+22 \mathrm{ppmv}$ at salinity 32 , precisely where the bloom of marine phytoplankton apparently occurred, possibly favoured by After a conversion to $\mathrm{CO}_{2}$ fluxes by applying a gas transfer velocity, the deviation between the T$615 \mathrm{pCO}_{2}$ and the modelled $\mathrm{Ex}-\mathrm{pCO}_{2}$ corrected for gas exchange, provide an indirect and integrative 616 estimate of NEP (Table 2). Quantitatively, the computed NEP (including tidal pumping) with this 617 original method in the São Francisco (Table 2), as well as in the Paraiba do Sul (Cotovicz et al., 618 2020) are around 1 or less $\mathrm{mmol} \mathrm{m}^{-2} \mathrm{~h}^{-1}$, when NEP reported in estuaries of the world varies 
619 between +5 (autotrophy) and $-12 \mathrm{mmol} \mathrm{m}^{-2} \mathrm{~h}^{-1}$ (heterotrophy) (Borges and Abril 2011). Despite

620 these low values, our method is quite sensitive and the sign and spatial distribution of the

621 calculated NEP are consistent with classical concepts of estuarine plankton ecology (Crump et al.,

622 2004; Lancelot and Muylaert, 2012), tidal advection and the short residence-time in the mixing

623 zone. This confirms the robustness of our approach that could be applied to many estuarine 624 environments, whether they act as $\mathrm{CO}_{2}$ sink or source.

\section{Conclusions}

The São Francisco Estuary displays specific conditions in terms of carbonate chemistry and airwater $\mathrm{CO}_{2}$ exchange: because of warm and poorly buffered freshwaters, oligotrophic conditions and short residence time, carbonate thermodynamic equilibration during mixing predominate over biological processes and determine water $p \mathrm{CO}_{2}$ and air-water $\mathrm{CO}_{2}$ fluxes. This results in an abiotic uptake of atmospheric $\mathrm{CO}_{2}$ by the estuary at salinities above 3 in the main channel and the DIC export to the sea is increased by $7-10 \%$. During winter and neap tide period, tidal pumping and heating were weak and the observed $\mathrm{pCO}_{2}$ almost matched the theoretical conservative mixing curve, within the error of measurements and computations. During summer and spring tide period, the observed $p \mathrm{CO}_{2}$ was still below the atmospheric value, but on average $+49 p p m v$ above the conservative mixing curve. At that season and salinities $>3$, heating of water relative to the mixing of the two end-members contributed to $\sim 15 \%$, and gas exchange contributed to $\sim 10 \%$ of the deviation of observed $\mathrm{pCO}_{2}$ from conservativity, the remaining $\sim 75 \%$ being attributed in majority to tidal pumping from mangroves and brackish marshes, maybe with some respiratory activity in estuarine waters despite the short residence time. Following the approach of Cotovicz et al. (2020)

642 in the mesotrophic and tropical Paraiba do Sul River delta that also behaves as a $\mathrm{CO}_{2}$ sink in the 643 mixing zone, our study is a second detailed report of $\mathrm{CO}_{2}$ air-water exchange, based on the 644 combination of high-resolution $\mathrm{pCO}_{2}$ field data and theoretical computation that cover the complete salinity gradient. We highlight a singular situation, not only occurring in the oligotrophic São Francisco, but also the mesotrophic Paraiba do Sul Estuary, of concomitant $\mathrm{CO}_{2}$ uptake and 
buffered freshwaters that potentially generates $\mathrm{CO}_{2}$ invasion in the mixing zone, occur in large tropical river plumes like the Amazon, Congo and Orinoco. High resolution $p \mathrm{CO}_{2}$ measurements along the entire salinity gradient of these large estuaries and plumes are thus necessary. In the Amazon plume, the available equilibrator $p \mathrm{CO}_{2}$ data covers only the $>17$ salinities range with undersaturated values with respect to the atmosphere, well below those predicted by the conservative mixing of Amazon river water with Atlantic equatorial water (Körtzinger, 2003; Lefèvre et al., 2017). This indicates that in the Amazon, thermodynamic and biological processes contribute together to $\mathrm{CO}_{2}$ invasion because the plume is autotrophic, whereas in the Paraiba do Sul and São Francisco Estuaries, the two processes are competing with each other both at low salinities (evasion and autotrophy) and high salinities (invasion and heterotrophy). High-resolution surface $p \mathrm{CO}_{2}$, temperature and salinity measurements coupled with modelling of estuarine mixing provided some detailed and precise information that could be applied in many plumes of large tropical rivers that contribute more significantly to the riverine carbon load to the world ocean.

\section{Acknowledgements}

This research was funded by the Brazilian National Council of Research and Technological Development (CNPq) through the Science without border program (PVE 401726-6), the Instituto do Milênio Estuários project (420.050/2005-1) and the National Institute of Science and Technology Transferências de Materiais Continente-Oceano (TCMOcean 573.601/2008-9). Georgenes H Cavalcante was supported by the American University of Sharjah (research Grant FRG19-M-G74). This work is also a contribution to the International Research Project Vulnérabilité des Ecosystèmes Littoraux Tropicaux face à l'Eutrophisation funded by the French National Centre for Scientific Research (CNRS-INEE).

\section{References}

Abril G. and Frankignoulle M. (2001) Nitrogen-Alkalinity interactions in the highly polluted Scheldt basin (Belgium). Water Res. 35, 844-850.

Abril G., Commarieu M.V., Sottolichio A., Bretel P. and Guérin F. (2009) Turbidity limits gas exchange in a large macrotidal estuary. Estuar. Coast. Shelf Sci. 83, 342-348. 
Abril G., Etcheber H., Borges A. V. \& Frankignoulle M. (2000) Excess atmospheric carbon dioxide transported by rivers into the Scheldt Estuary. C. R. Acad. Sci. Paris Série IIA 330, 761-768. Abril, G., Etcheber, H., Delille, B., Frankignoulle, M., Borges, A. V., (2003). Carbonate dissolution in the turbid and eutrophic Loire estuary. Mar. Ecol. Prog. Ser. 259, 129-138.

Bauer J. E., Cai W. J., Raymond P., Bianchi T. S., Hopkinson C. S. and Regnier P. G. (2013) The changing carbon cycle of the coastal ocean. Nature 504, 61-70.

Bernardes, L. M. C., (1951). Notas sobre o clima da bacia do Rio são Francisco. Rev. Bras. Geogr. 13, 473-489.

Bernardes, M. C., Knoppers, B. A., Rezende, C. E., Souza, W. F. L., Ovalle, A. R. C. (2012). Landsea interface features of four estuaries on the South America Atlantic coast. Braz. J. Biol, 72, 761-774. dx.doi.org/10.1590/S1519-69842012000400011.

Borges A. V. and Abril G. (2011) Carbon dioxide and methane dynamics in estuaries. In Treatise on estuarine and coastal science (eds. E. Wolanski and D. D. McLusky), vol 5, Academic Press, Amsterdam. pp. 119-161.

Borges A. V., Schiettecatte L.-S., Abril G., Delille B. and Gazeau F. (2006) Carbon dioxide in European Coastal waters. Estuar. Coast. Shelf Sci. 70, 375-387.

Borges, A. V., Djenidi, S., Lacroix, G., Theate, J., Delille, B., Frankignoulle, M. (2003). Atmospheric CO2 flux from mangrove surrounding waters. Geophys. Res. Lett. 30, 1558.

Borges, A. V., Delille, B., Schiettecatte, L.-S., Gazeau, F., Abril, G., Frankignoulle M., (2004). Gas transfer velocity of $\mathrm{CO} 2$ in three European estuaries (Randers Fjord, Scheldt and Thames). Limnol. Oceanogr. 49, 1630-1641.

Borges, A.V. (2005). Do we have enough pieces of the jigsaw to integrate CO2 fluxes in the Coastal Ocean? Estuaries 28, 3-27.

Bouillon S., Frankignoulle M., Dehairs F., Velimirov B., Eiler A., Abril G., Etcheber H. \& Borges A.V. (2003) Inorganic and organic carbon biogeochemistry in the Gautami Godavari estuary (Andhra Pradesh, India) during pre-monsoon: the local impact of extensive mangrove forests. Global Biogeochem. Cy. 17, 1114.

Cai W. J. (2011) Estuarine and coastal ocean carbon paradox: CO2 sinks or sites of terrestrial carbon incineration? Ann. Rev. Mar. Sci. 3, 123-145. 
Cai W. J., Chen A. C., and Borges A. V. (2013). Carbon dioxide dynamics and fluxes in coastal waters influenced by river plumes. In Biogeochemical Dynamics at Major River-Coastal Interfaces: Linkages with Global Change (eds. T. Bianchi, M. Allison, and W. Cai) Cambridge University Press. pp. 155-173. doi:10.1017/CBO9781139136853.010

Cavalcante G., Miranda L.B., and Medeiros P. R. P. (2017) Circulation and salt balance in the São Francisco river Estuary (NE/Brazil). Revista Brasileira de Recursos Hídricos, 22. doi.org/10.1590/2318-0331.021720170003.

Cavalcante G., Vieira F., Campos E., Brandini N., Medeiros P.R.P. (2020) Temporal streamflow reduction and impact on the salt dynamics of the São Francisco River Estuary and adjacent coastal zone (NE/Brazil). Regional Studies in Marine Science 38: 101363. doi.org/10.1016/j.rsma.2020.101363.

Chen C. T. A. and Borges A. V. (2009) Reconciling opposing views on carbon cycling in the coastal ocean: continental shelves as sinks and near-shore ecosystems as sources of atmospheric $\mathrm{CO}_{2}$. Deep Sea Res. Part 2 Top. Stud. Oceanogr. 56, 578-590.

Cloern J. E. (1996) Phytoplankton bloom dynamics in coastal ecosystem: a review with some general lessons from sustained investigation of San Francisco Bay, California. Rev. Geophys. 34: 127-168.

Cotovicz Jr., L. C., Knoppers B. A., Brandini N., Costa Santos S. J. and Abril G. (2015) A strong CO2 sink enhanced by eutrophication in a tropical coastal embayment (Guanabara Bay, Rio de Janeiro, Brazil). Biogeosciences 12, 6125-6146.

Cotovicz Jr., L.C., Libardoni, B., Brandini, N., Knoppers, B., Abril, G. (2016) Comparações entre medições em tempo real da pCO2 aquática com estimativas indiretas em dois estuárioss tropicais contrastantes: o estuário eutrofizado da Baia de Guanabara (RJ) e o estuário oligotrofico do Rio São Francisco (AL). Quím. Nova 39, 1206-1214

Cotovicz Jr., L. C., Vidal, L. O., de Rezende, C. E., Bernardes, M. C., Knoppers, B. A., Sobrinho, R., L., Cardoso, R. P., Muniz, M., dos Anjos, R. M., Biehler, A., Abril, G. (2020) Carbon dioxide sources and sinks in the delta of the Paraíba do Sul River (Southeastern Brazil) modulated by carbonate thermodynamics, gas exchange and ecosystem metabolism during estuarine mixing. Mar. Chem. 226 (20), 103869. 
Cotovicz Jr., L. C., Ribeiro, R., Régis, C. R., Bernardes, M., Sobrinho, R., Vidal, L. O., Tremmel, D., Knoppers, B. A., Abril, G. (2021) Greenhouse gas emissions $\left(\mathrm{CO}_{2}\right.$ and $\left.\mathrm{CH}_{4}\right)$ and inorganic carbon behavior in an urban highly polluted tropical coastal lagoon (SE, Brazil). Environ. Sci. Pollut. Res., doi: 10.1007/s11356-021-13362-2

Crump, B. C., Hopkinson, C. S., Sogin, M. L. and Hobbie, J. E. (2004) Microbial biogeography along an estuarine salinity gradient: combined influences of bacterial growth and residence time. Appl. Environ. Microbiol. 70, 1494-1505.2

de Jong, P., Tanajura, C. A. S., Sánchez, A. S., Dargaville, R., Kiperstok, A., Torres, E. A (2018). Hydroelectric production from Brazil's São Francisco River could cease due to climate change and inter-annual variability. Sci. Total Environ. 634, 1540-1553.

Delaigue L., Thomas H., and Mucci A. (2020) Spatial variations in CO2 fluxes in the Saguenay Fjord (Quebec, Canada) and results of a water mixing model. Biogeosciences, 17, 547-566, doi:10.5194/bg-17-547-2020

Dickson, A. G., Millero, F. J. (1987). A comparison of the equilibrium constants for the dissociation of carbonic acid in seawater media. Deep-Sea Res. 34, 1733-1743.

Dinauer, A. ; Mucci, A. (2017). Spatial variability in surface-water pCO2 and gas exchange in the world's largest semi-enclosed estuarine system: St. Lawrence Estuary (Canada). Biogeosciences, 14, 3221-3237.

Dominguez, J. M. L., (1996). The São Francisco strandplain: a paradigm for wave-dominated deltas? Geology Society London, Spec. Publ. 117, 217-231.

Etemad-Shahidi A. and Imberger J. (2002) Anatomy of turbulence in a narrow and strongly stratified estuary. J. Geophys. Res. 107, 3070, doi10.1029/2001JC000977

Frankignoulle M., Abril G., Borges A., Bourge I., Canon C., Delille B., Libert E. and Théate J. M. (1998) Carbon dioxide emission from European estuaries. Science 282, 434-436.

Frankignoulle M., Bourge I., and Wollast R. (1996) Atmospheric CO2 fluxes in a highly polluted estuary (The Scheldt), Limnol. Oceanogr. 41, 365-369.

Frankignoulle, M., Borges, A. V., and Biondo, R. (2001) A new design of equilibrator to monitor carbon dioxide in highly dynamic and turbid environments. Water Res. 35, 1344-1347. 
Grodsky S. A., Reverdin G., Carton J.A. and Coles V. J. (2014) Year-to-year salinity changes in the Amazon plume: Contrasting 2011 and 2012 Aquarius/SACD and SMOS satellite data Remote Sens. Envir. 140, 14-22.

Hunt, C. W., Salisbury, J. E. and Vandemark, D.: Contribution of non-carbonate anions to total alkalinity and overestimation of pCO2 in New England and New Brunswick rivers. Biogeosciences, 8, 3069-3076, 2011.

Körtzinger A. (2003). A significant $\mathrm{CO}_{2}$ sink in the tropical Atlantic Ocean associated with the Amazon river plume. Geophys. Res. Lett. 30, 2287, doi:10.1029/2003GL018841.

Lancelot, C., Muylaert, K. (2012). Trends in Estuarine Phytoplankton Ecology. In Treatise on estuarine and coastal science (eds. E. Wolanski and D. D. McLusky), Vol 7, Academic Press, Amsterdam. pp. 5-15.

Lefèvre N., Flores Montes M., Gaspar F. L., Rocha C., Jiang S., De Araújo M. C. and Ibánhez J. S. P. (2017) Net Heterotrophy in the Amazon Continental Shelf Changes Rapidly to a Sink of $\mathrm{CO}_{2}$ in the Outer Amazon Plume. Front. Mar. Sci. 4, 278. doi:0.3389/fmars.2017.00278

Leopold A., Marchand C., Deborde J. and Allenbach M. (2016) Water Biogeochemistry of a Mangrove-Dominated Estuary Under a Semi-Arid Climate (New Caledonia). Estuar. Coast. 40, 773-791.

Maher D. T., Call M., Santos I. R., Sanders C. (2018) Beyond burial: lateral exchange is a significant atmospheric carbon sink in mangrove forests. Biol. Lett. 14, doi :10.1098/rsbl.2018.0200

Maher D. T., Santos I. R., Golsby-Smith L., Gleeson J. and Eyre B. D. (2013) Groundwater-derived dissolved inorganic and organic carbon exports from a mangrove tidal creek: The missing mangrove carbon sink? Limnol. Oceanogr. 58, 475-488.

Medeiros P. R. P., Knoppers B. A., dos Santos Júnior R. C. and de Souza W.F.L. (2007) Aporte fluvial e dispersão de matéria particulada em suspensão na zona costeira do Rio São Francisco (SE/AL) Geochimica Brasiliensis, 21(2)212 - 231, 2007.

Medeiros P. P. M., Knoppers B. A., Cavalcante G. H., de Souza W. F. L. (2011) Changes in Nutrient Loads (N, P and Si) in the São Francisco Estuary after the Construction of Dams. Braz. Arch. Biol. Technol. 54, 387-397. 
Medeiros P. R. P., Cavalcante G. H. , Melo E. R. and Brandini N. (2018) The são Francisco river (NE): review on the interannual loading of particulate matter suspended to the ocean and impacts of dams. Int. J. Hydrol.. 2,190-193. doi:10.15406/ijh.2018.02.00067

Mehrbach C., Culberson, C. H. Hawley J. E., Pytkowicz R.M. (1973). Measurements of the apparent dissociation constants of carbonic acid in seawater at atmospheric pressure. Limnol. Oceanogr. 18, 897-907.

Melo, E. R., Brandini, N., Medeiros, P. R. P., Silva, R., and Cavalcante, G. (2020). Nutrients Load Estimation in a Regulated Streamflow Estuary: The São Francisco Estuary (NE/Brazil). Revista Brasileira de Meteorologia. 35, 803-811.

Melo-Magalhães E.M., Moura A.N., Medeiros P.R.P. and Koening M.L. (2015) Microphytoplankton biomass and trophic state of the estuarine region of the São Francisco River (Northeastern Brazil) Braz. J. Aquat. Sci. Technol., 20, 19-30.

Murgulet, D., Trevino M., Douglas A., Spalt N., Hu X., and Murgulet V. (2018). Temporal and spatial fluctuations of groundwater-derived alkalinity fluxes to a semiarid coastal embayment. Sci. Total Environ. 630, 1343-59. doi:10.1016/ j.scitotenv.2018.02.333

Neubauer S.C., Anderson, I.C. (2003). Transport of dissolved inorganic carbon from a tidal freshwater marsh to the York River estuary. Limnol. Oceanogr. 48, 299-307.

Orton P.M. Zappa C.J. and McGillins W.R. (2010) Tidal and atmospheric influences on nearsurface turbulence in an estuary. J. Geophys. Res. 115: C12029, doi:10.1029/2010JC006312.

Phillipson L. and Toumi R. (2020) Assimilation of Satellite Salinity for Modelling the Congo River Plume. Remote Sens. 12, 11; doi:10.3390/rs12010011

Pierrot D., Lewis D. E., and Wallace D. W. R. (2006). MS Excel Program Developed for CO2 System Calculations. ORNL/CDIAC-105a. Carbon Dioxide Information Analysis Center, Oak Ridge National Laboratory, U.S. Department of Energy, Oak Ridge, Tennessee. doi: 10.3334/CDIAC/otg.CO2SYS_XLS_CDIAC105a

Raymond P.A., Cole J. J. (2001). Gas exchange in rivers and estuaries: choosing a gas transfer velocity. Estuaries 24: 312-317. 
Santos, I. R., Maher, D. T., Larkin, R., Webb, J., Sanders, C. J. (2018) Carbon outwelling and outgassing vs. burial in an estuarine tidal creek surrounded by mangrove and saltmarsh wetlands. Limnol. Oceangr. Letters 2, 1-18. doi.org/10.1002//no.11090.

Sarma, V., Viswanadham, R., Rao, G. D., Prasad, V. R., Kumar, B. S. K., Naidu, S. A., Kumar, N. A., Rao, D. B., Sridevi, T., Krishna, M. S., Reddy, N. P. C., Sadhuram, Y., Murty, T. V. R. (2012) Carbon dioxide emissions from Indian monsoonal estuaries, Geophys. Res. Lett., 39, L03602, doi:10.1029/2011gl050709.

Smith S.V. and Hollibaugh J.T. (1993). Coastal metabolism and the oceanic carbon balance. Rev. Geophys. 31, 75-89.

Takahashi T., Sutherland S. C., Sweeney C., Poisson A., Metzl N., Tilbrook B., Bates N., Wanninkhof R., Feely R. a., Sabine C., Olafsson J. and Nojiri Y. (2002) Global sea-air CO2 flux based on climatological surface ocean $\mathrm{pCO} 2$, and seasonal biological and temperature effects. Deep. Sea Res. Part // 49, 1601-1622.

Wanninkhof, R. (1992). Relationship between wind speed and gas exchange over the ocean. J. Geophys. Res. 97, 7373-7382.

Weiss R. F. (1974). Carbon dioxide in water and seawater: the solubility of a non-ideal gas. Mar. Chem. 2, 203-215.

Whitfield, M. and Turner D. R. (1986) The carbon dioxide system in estuaries - An inorganic perspective. Sci. Total Environ. 49, 235-255.

Wollast R. (1991). The coastal organic carbon cycle: fluxes, sources, and sinks. In Ocean Margin Processes in Global Change (eds. Mantoura, R. F. C., Martin, J.M., Wollast, R.) Wiley, Chichester, West Sussex, England, pp. 365-381.

Yao H. and $\mathrm{Hu}$ X. (2017) Responses of carbonate system and $\mathrm{CO}_{2}$ flux to extended drought and intense flooding in a semiarid subtropical estuary. Limnol. Oceanogr. 62 S112-S130.

Yao H., McCutcheon M.R., Staryk C.J. and Hu X. (2020) Hydrologic controls on $\mathrm{CO}_{2}$ chemistry and flux in subtropical lagoonal estuaries of the northwestern Gulf of Mexico. Limnol. Oceanogr. 9999, 2020, 1-19. doi:10.1002//no.11394. 
849

850

851

852

853 
Table 1. Synthesis of measured and calculated parameters during the two cruises. O- $p \mathrm{CO}_{2}$ is the observed $p \mathrm{CO}_{2}$ as measured in situ, $\mathrm{C}-p \mathrm{CO}$ is the conservative $p \mathrm{CO}_{2}$ modelled from mixing of river water with seawater, T- $p \mathrm{CO}_{2}$ is the $p \mathrm{CO}_{2}$ normalized to temperature resulting from the mixing of the two end-members and $\mathrm{Ex}-p \mathrm{CO}_{2}$ is the $p \mathrm{CO}_{2}$ resulting from conservative after being corrected for gas exchange. ${ }^{*} \mathrm{Calculated}$ using the mixing/gas exchange model described in Fig.5, for the measured U10, a value of RT of 0.5 days and $\mathrm{H}$ of $3 \mathrm{~m}$. \# During night, measured and modelled conservative $p \mathrm{CO}_{2}$ values are lower than expected when compared to the daytime, because night-time measurements did not include samples with salinities lower than 1.2 and highest $\mathrm{pCO}_{2} .{ }^{\$}$ In order to account for the protection of mangrove trees to creek waters, we divided by 2 the wind speed values to calculate $\mathrm{CO}_{2}$ fluxes from the mangrove secondary channel, as a first approximation. Standard deviation of the differences between two numbers were calculated as the square root of the sum of the squares of the two errors. 


\begin{tabular}{|c|c|c|c|c|c|c|c|c|}
\hline & \multicolumn{3}{|c|}{ Aug. 2014} & \multicolumn{5}{|c|}{ Nov. 2015} \\
\hline & \multicolumn{2}{|c|}{ Main Channel } & \multirow{3}{*}{$\begin{array}{c}\text { Mangrove } \\
\text { S }>3 \\
\text { Day }\end{array}$} & \multicolumn{4}{|c|}{ Main Channel } & \multirow{3}{*}{$\begin{array}{c}\text { Mangrove } \\
S>3 \\
\text { Day }\end{array}$} \\
\hline & $S<3$ & $S>3$ & & \multicolumn{2}{|c|}{$\mathrm{S}<3$} & \multicolumn{2}{|c|}{$S>3$} & \\
\hline & Day & Day & & Day & Night ${ }^{\#}$ & Day & Night & \\
\hline Number of measurements & 321 & 190 & 324 & 518 & 260 & 701 & 441 & 528 \\
\hline Temperature $\left({ }^{\circ} \mathrm{C}\right)$ & $\begin{array}{r}26.6 \pm 0.2 \\
26.1-27.0\end{array}$ & $\begin{array}{r}26.5 \pm 0.1 \\
26.4-26.7 \\
\end{array}$ & $\begin{array}{r}26.7 \pm 0.4 \\
26.1-27.3 \\
\end{array}$ & $\begin{array}{r}28.3 \pm 0.4 \\
27.5-29.2\end{array}$ & $\begin{array}{r}27.9 \pm 0.2 \\
27.6-28.2\end{array}$ & $\begin{array}{r}28.1 \pm 0.4 \\
27.0-28.9\end{array}$ & $\begin{array}{r}27.7 \pm 0.5 \\
26.8-28.4 \\
\end{array}$ & $\begin{array}{r}28.3 \pm 0.9 \\
26.3-29.8 \\
\end{array}$ \\
\hline $\mathrm{O}-p \mathrm{CO}_{2}(\mathrm{ppmv})$ & $\begin{array}{r}752 \pm 308 \\
245-2137 \\
\end{array}$ & $\begin{array}{r}279 \pm 34 \\
224-355 \\
\end{array}$ & $\begin{array}{r}512 \pm 191 \\
298-975 \\
\end{array}$ & $\begin{array}{r}426 \pm 141 \\
233-1040 \\
\end{array}$ & $\begin{array}{r}421 \pm 60 \\
304-514 \\
\end{array}$ & $\begin{array}{r}344 \pm 39 \\
259-423 \\
\end{array}$ & $\begin{array}{r}311 \pm 30 \\
267-383 \\
\end{array}$ & $\begin{array}{r}976 \pm 314 \\
307-2007 \\
\end{array}$ \\
\hline $\mathrm{C}-p \mathrm{CO}_{2}(\mathrm{ppmv})$ & $\begin{array}{r}634 \pm 92 \\
371-710 \\
\end{array}$ & $\begin{array}{r}282 \pm 33 \\
233-343 \\
\end{array}$ & $\begin{array}{r}296 \pm 36 \\
232-368 \\
\end{array}$ & $\begin{array}{r}542 \pm 123 \\
318-646 \\
\end{array}$ & $\begin{array}{l}392 \pm 34^{*} \\
298-476\end{array}$ & $\begin{array}{r}295 \pm 46 \\
238-411 \\
\end{array}$ & $\begin{array}{r}275 \pm 31 \\
238-363 \\
\end{array}$ & $\begin{array}{r}334 \pm 41 \\
238-406 \\
\end{array}$ \\
\hline$\overline{\mathrm{T}-p \mathrm{CO}_{2}(\mathrm{ppmv})}$ & $\begin{array}{r}753 \pm 311 \\
245-2166 \\
\end{array}$ & $\begin{array}{r}279 \pm 34 \\
224-357 \\
\end{array}$ & $\begin{array}{r}503 \pm 185 \\
293-949 \\
\end{array}$ & $\begin{array}{r}421 \pm 144 \\
228-1043 \\
\end{array}$ & $\begin{array}{r}420 \pm 61 \\
299-512 \\
\end{array}$ & $\begin{array}{r}332 \pm 37 \\
252-405 \\
\end{array}$ & $\begin{array}{r}307 \pm 29 \\
264-373 \\
\end{array}$ & $\begin{array}{r}917 \pm 292 \\
297-1956 \\
\end{array}$ \\
\hline$\overline{E x}-p \mathrm{CO}_{2}(p p m v)$ & $\begin{array}{r}622 \pm 95 \\
357-692 \\
\end{array}$ & $\begin{array}{r}284 \pm 34 \\
236-344\end{array}$ & - & $\begin{array}{r}530 \pm 125 \\
307-635\end{array}$ & $\begin{array}{l}386 \pm 36^{*} \\
294-472\end{array}$ & $\begin{array}{r}299 \pm 47 \\
238-411\end{array}$ & $\begin{array}{r}280 \pm 32 \\
241-369 \\
\end{array}$ & - \\
\hline $\mathrm{O}-p \mathrm{CO}_{2}-\mathrm{C}-p \mathrm{CO}_{2}(\mathrm{ppmv})$ & $\begin{array}{r}117 \pm 256 \\
-243-1444\end{array}$ & $\begin{array}{r}-3 \pm 13 \\
-65-69\end{array}$ & $\begin{array}{r}216 \pm 180 \\
40-680\end{array}$ & $\begin{array}{r}-104 \pm 90 \\
-413-407\end{array}$ & $\begin{array}{r}29 \pm 21 \\
-64-101\end{array}$ & $\begin{array}{r}49 \pm 39 \\
-31-141\end{array}$ & $\begin{array}{r}36 \pm 22 \\
-41-111\end{array}$ & $\begin{array}{r}643 \pm 320 \\
-11-1671\end{array}$ \\
\hline $\mathrm{O}-p \mathrm{CO}_{2}-\mathrm{T}-p \mathrm{CO}_{2}(\mathrm{ppmv})$ & $\begin{array}{r}-1 \pm 7 \\
-29-9 \\
\end{array}$ & $\begin{array}{l}0 \pm 1 \\
-2-3 \\
\end{array}$ & $\begin{array}{r}9 \pm 8 \\
-1-30 \\
\end{array}$ & $\begin{array}{r}5 \pm 7 \\
-6-19 \\
\end{array}$ & $\begin{array}{l}2 \pm 2 \\
-3-6 \\
\end{array}$ & $\begin{array}{r}12 \pm 8 \\
-10-25 \\
\end{array}$ & $\begin{array}{r}5 \pm 3 \\
-3-11 \\
\end{array}$ & $\begin{array}{r}59 \pm 40 \\
-10-124 \\
\end{array}$ \\
\hline 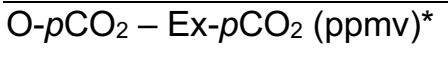 & $-12 \pm 9$ & $2 \pm 2$ & - & $-12 \pm 9$ & $-6 \pm 3$ & $4 \pm 3$ & $4 \pm 3$ & - \\
\hline $\mathrm{U}_{10}\left(\mathrm{~m} \mathrm{~s}^{-1}\right)$ & $\begin{array}{l}1.1 \pm 0.7 \\
0.1-2.8 \\
\end{array}$ & $\begin{array}{l}1.1 \pm 0.7 \\
0.1-2.8 \\
\end{array}$ & $\begin{array}{r}0.6 \pm 0.4 \\
0.5-1.4 \\
\end{array}$ & $\begin{array}{r}2.2 \pm 1.0 \\
0.9-3.2 \\
\end{array}$ & $\begin{array}{r}0.4 \pm 0.2 \\
0.1-1.1 \\
\end{array}$ & $\begin{array}{r}2.2 \pm 1.0 \\
0.9-3.2 \\
\end{array}$ & $\begin{array}{r}0.4 \pm 0.2 \\
0.1-1.1 \\
\end{array}$ & $\begin{array}{l}1.1 \pm 0.5^{\$} \\
0.5-1.6^{\$}\end{array}$ \\
\hline $\mathrm{k}_{600}\left(\mathrm{~cm} \mathrm{~h}^{-1}\right)$ W92 & 0.6 & 0.6 & 0.2 & 1.6 & 0.1 & 1.6 & 0.1 & 0.5 \\
\hline $\mathrm{K}_{600}\left(\mathrm{~cm} \mathrm{~h}^{-1}\right) \mathrm{RC01}$ & 3.4 & 3.4 & 2.9 & 4.1 & 2.2 & 4.1 & 2.2 & 2.8 \\
\hline $\mathrm{K}_{600}\left(\mathrm{~cm} \mathrm{~h}^{-1}\right) \mathrm{A} 09$ & 5.6 & 5.6 & 4.1 & 7.3 & 2.8 & 7.3 & 2.8 & 4.6 \\
\hline $\mathrm{FCO}_{2} \mathrm{~W} 92\left(\mathrm{mmol} \mathrm{m}^{-2} \mathrm{~h}^{-1}\right)$ & $0.74 \pm 0.30$ & $-0.25 \pm 0.03$ & $0.09 \pm 0.03$ & $0.18 \pm 0.06$ & $0.01 \pm 0.00$ & $-0.38 \pm 0.04$ & $-0.04 \pm 0.00$ & $1.23 \pm 0.40$ \\
\hline $\mathrm{FCO}_{2} \mathrm{RC} 01\left(\mathrm{mmol} \mathrm{m} \mathrm{m}^{-2} \mathrm{~h}^{-1}\right)$ & $3.93 \pm 1.61$ & $-1.35 \pm 0.17$ & $1.05 \pm 0.39$ & $0.44 \pm 0.15$ & $0.19 \pm 0.03$ & $-0.94 \pm 0.11$ & $-0.78 \pm 0.07$ & $6.55 \pm 2.11$ \\
\hline $\mathrm{FCO}_{2} \mathrm{~A} 09\left(\mathrm{mmol} \mathrm{m}^{-2} \mathrm{~h}^{-1}\right)$ & $6.43 \pm 2.64$ & $-2.21 \pm 0.27$ & $1.48 \pm 0.55$ & $0.79 \pm 0.26$ & $0.24 \pm 0.03$ & $-1.68 \pm 0.19$ & $-1.01 \pm 0.10$ & $10.72 \pm 3.45$ \\
\hline
\end{tabular}


2 Table 2. Comparison of binned data with modelled data for the Nov. 2005 campaign. *Calculated

3 as $\mathrm{O}-p \mathrm{CO}_{2}$ minus $\mathrm{T}-p \mathrm{CO}_{2} .{ }^{\#}$ Calculated as $\mathrm{C}-p \mathrm{CO}_{2}$ minus Ex- $p \mathrm{CO}_{2} .{ }^{\$}$ Calculated as

$4 \mathrm{O}-p \mathrm{CO}_{2}$ minus $\mathrm{C}-p \mathrm{CO}_{2}$ minus T- $p \mathrm{CO}_{2}$ minus Ex- $p \mathrm{CO}_{2}$. Standard deviation of the differences

5 between two numbers were calculated as the square root of the sum of the squares of the two

6 errors.

\begin{tabular}{|c|c|c|c|c|}
\hline & $\mathrm{S}<3$ & $\mathrm{~S}<3$ & $S>3$ & $S>3$ \\
\hline & Day & Night & Day & Night \\
\hline \multicolumn{5}{|l|}{$\mathrm{pCO}_{2}$ (ppmv) } \\
\hline Number of measurements & 518 & 260 & 701 & 441 \\
\hline Salinity range & $0-2.9$ & $1.2-3.0$ & $3.1-35.1$ & 3.0-30.6 \\
\hline Temperature & $28.3 \pm 0.4$ & $27.9 \pm 0.2$ & $28.1 \pm 0.4$ & $27.7 \pm 0.5$ \\
\hline $\mathrm{O}-\mathrm{pCO}_{2}$ & $426 \pm 141$ & $421 \pm 60$ & $344 \pm 39$ & $311 \pm 30$ \\
\hline $\mathrm{T}-p \mathrm{CO}_{2}$ & $421 \pm 144$ & $420 \pm 61$ & $332 \pm 37$ & $307 \pm 29$ \\
\hline $\mathrm{C}-p \mathrm{CO}_{2}$ & $542 \pm 123$ & $392 \pm 34$ & $295 \pm 46$ & $275 \pm 31$ \\
\hline $\mathrm{Ex}-p \mathrm{CO}_{2}$ & $530 \pm 123$ & $386 \pm 35$ & $297 \pm 46$ & $277 \pm 31$ \\
\hline \multicolumn{5}{|l|}{ Components of $\mathrm{pCO}_{2}$ deviations (ppmv) } \\
\hline Heating $(+)$ / Cooling $(-)^{*}$ & $+5 \pm 7$ & $+2 \pm 2$ & $+12 \pm 8$ & $+5 \pm 3$ \\
\hline Invasion (+) / Evasion $(-)^{\#}$ & $-12 \pm 8$ & $-6 \pm 3$ & $+4 \pm 3$ & $+4 \pm 3$ \\
\hline Heterotrophy and tidal pumping $(+) /$ autotrophy $(-)^{\$}$ & $-97 \pm 77$ & $+34 \pm 19$ & $+33 \pm 25$ & $+27 \pm 17$ \\
\hline Sum & $-104 \pm 90$ & $+29 \pm 21$ & $+49 \pm 39$ & $+36 \pm 22$ \\
\hline \multicolumn{5}{|l|}{ Gas exchange parameters } \\
\hline $\mathrm{U} 10\left(\mathrm{~m} \mathrm{~s}^{-1}\right)$ & $2.2 \pm 1$ & $0.4 \pm 0.2$ & $2.2 \pm 1$ & $0.4 \pm 0.2$ \\
\hline $\mathrm{k}_{600}\left(\mathrm{~cm} \mathrm{~h}^{-1}\right) \mathrm{W} 92$ & 1.6 & 0.1 & 1.6 & 0.1 \\
\hline $\mathrm{k}_{600}\left(\mathrm{~cm} \mathrm{~h}^{-1}\right) \mathrm{RC} 01$ & 4.1 & 2.2 & 4.1 & 2.2 \\
\hline $\mathrm{k}_{600}\left(\mathrm{~cm} \mathrm{~h}^{-1}\right) \mathrm{A} 09$ & 7.3 & 2.8 & 7.3 & 2.8 \\
\hline \multicolumn{5}{|l|}{$\mathrm{CO}_{2}$ Fluxes $\left(\mathrm{mmol} \mathrm{m}^{-2} \mathrm{~h}^{-1}\right)$} \\
\hline Water-air $\mathrm{CO} 2$ flux calculated with observations & $+0.47 \pm 0.31$ & $+0.15 \pm 0.12$ & $-1.00 \pm 0.65$ & $-0.61 \pm 0.51$ \\
\hline Water-air flux calculated with conservative mixing & $+2.53 \pm 1.65$ & $-0.05 \pm 0.05$ & $-1.86 \pm 0.51$ & $-0.86 \pm 0.72$ \\
\hline Deviation of observations from conservative mixing & $-2.06 \pm 0.97$ & $+0.20 \pm 0.07$ & $+0.86 \pm 0.48$ & $+0.25 \pm 0.51$ \\
\hline \multicolumn{5}{|c|}{ Contributions to the deviation of $\mathrm{CO}_{2}$ fluxes $\left(\mathrm{mmol} \mathrm{m} \mathrm{m}^{-2} \mathrm{~h}^{-1}\right)$} \\
\hline Heating $(+)$ / Cooling $(-)$ & $+0.10 \pm 0.06$ & $+0.01 \pm 0.01$ & $+0.20 \pm 0.14$ & $+0.10 \pm 0.06$ \\
\hline Invasion (+) / Evasion (-) & $-0.21 \pm 0.14$ & $-0.04 \pm 0.03$ & $+0.03 \pm 0.02$ & $+0.01 \pm 0.03$ \\
\hline Heterotrophy plus tidal pumping $(+)$ / autotrophy $(-)$ & $-1.94 \pm 1.31$ & $+0.23 \pm 0.20$ & $+0.62 \pm 0.41$ & $+0.14 \pm 0.45$ \\
\hline
\end{tabular}




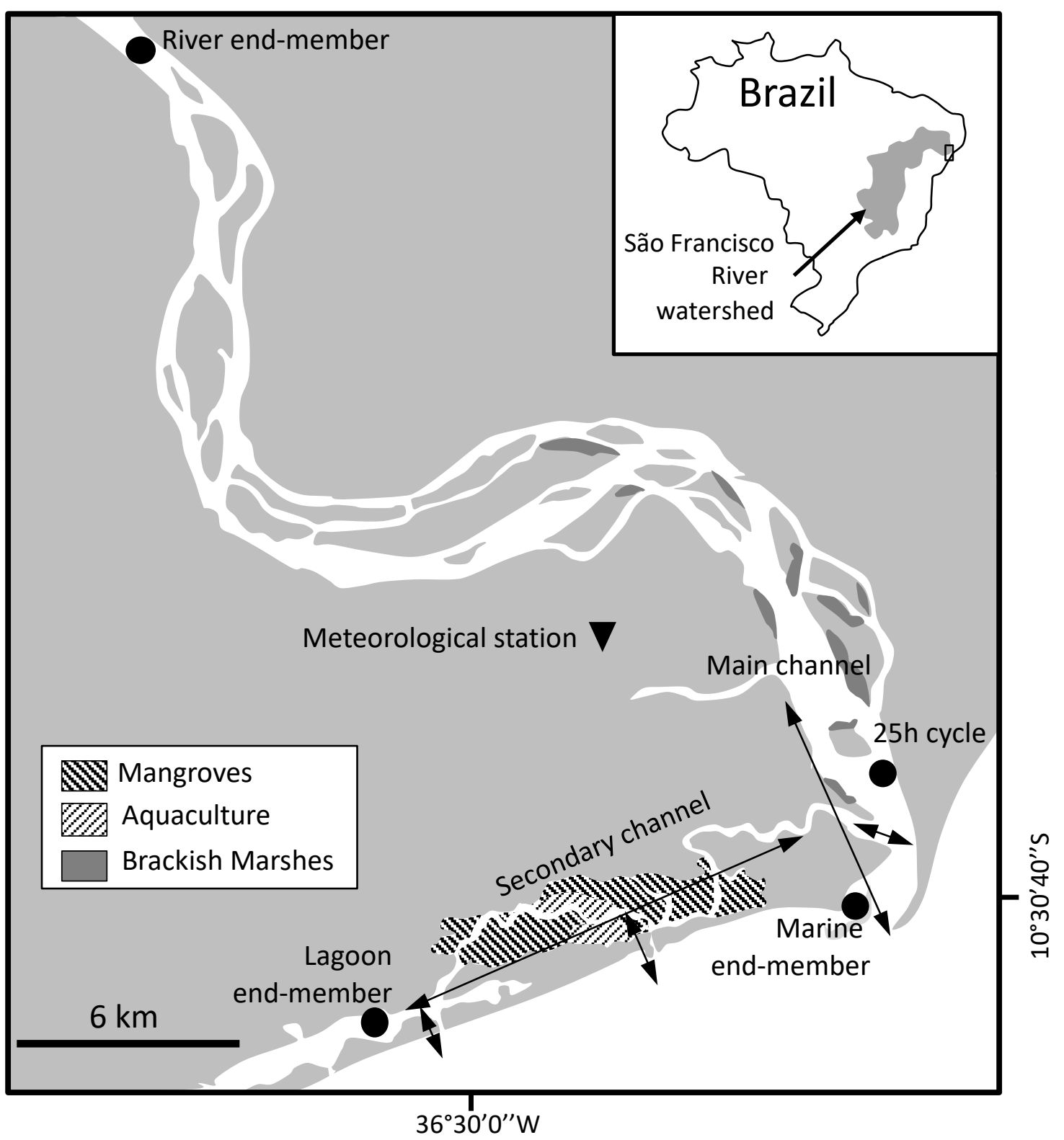

12 Figure 1. Map of the São Francisco Estuary. Arrows show the regions of freshwater-estuarine water-seawater mixing and the approximate localisation of the salinity gradient in the main

14 channel, sampled from the freshwater at the centre of the river until the seawater end-member 15 (Salinity 30-34) and in the shallow tidal lagoon end-member (Salinity 34). 


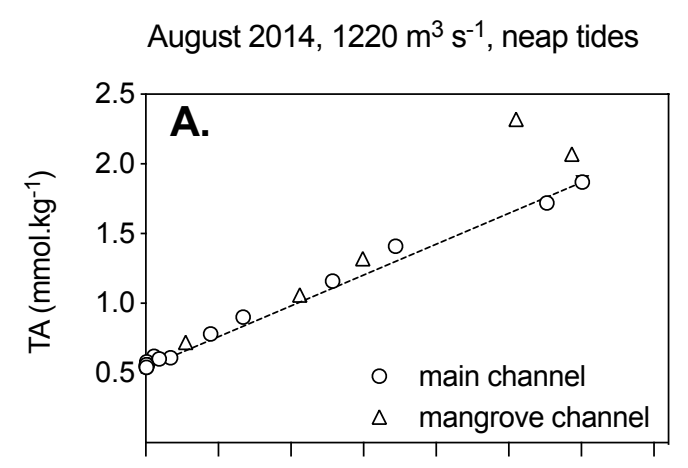

November 2015, $950 \mathrm{~m}^{3} \mathrm{~s}^{-1}$, spring tides
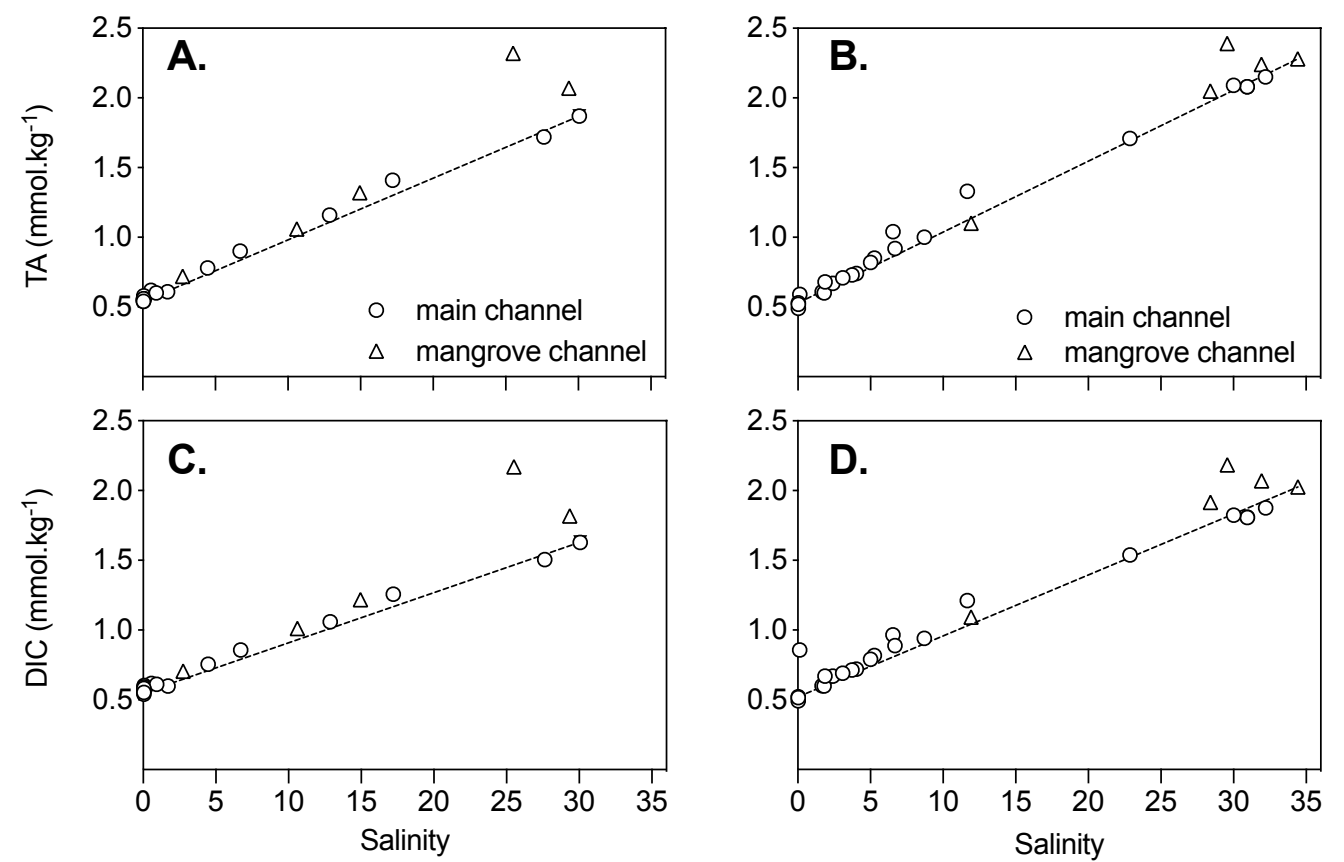

21 Figure 2: Distribution of Total Alkalinity (TA) (A. and B.) and Dissolved Inorganic Carbon (DIC) (C.

22 and D.) concentrations as a function of salinity in the São Francisco estuary main channel (circles)

23 and mangrove secondary channel (triangles) in August 2014 (A. and C.) and November 2015 (B.

24 and D.). 

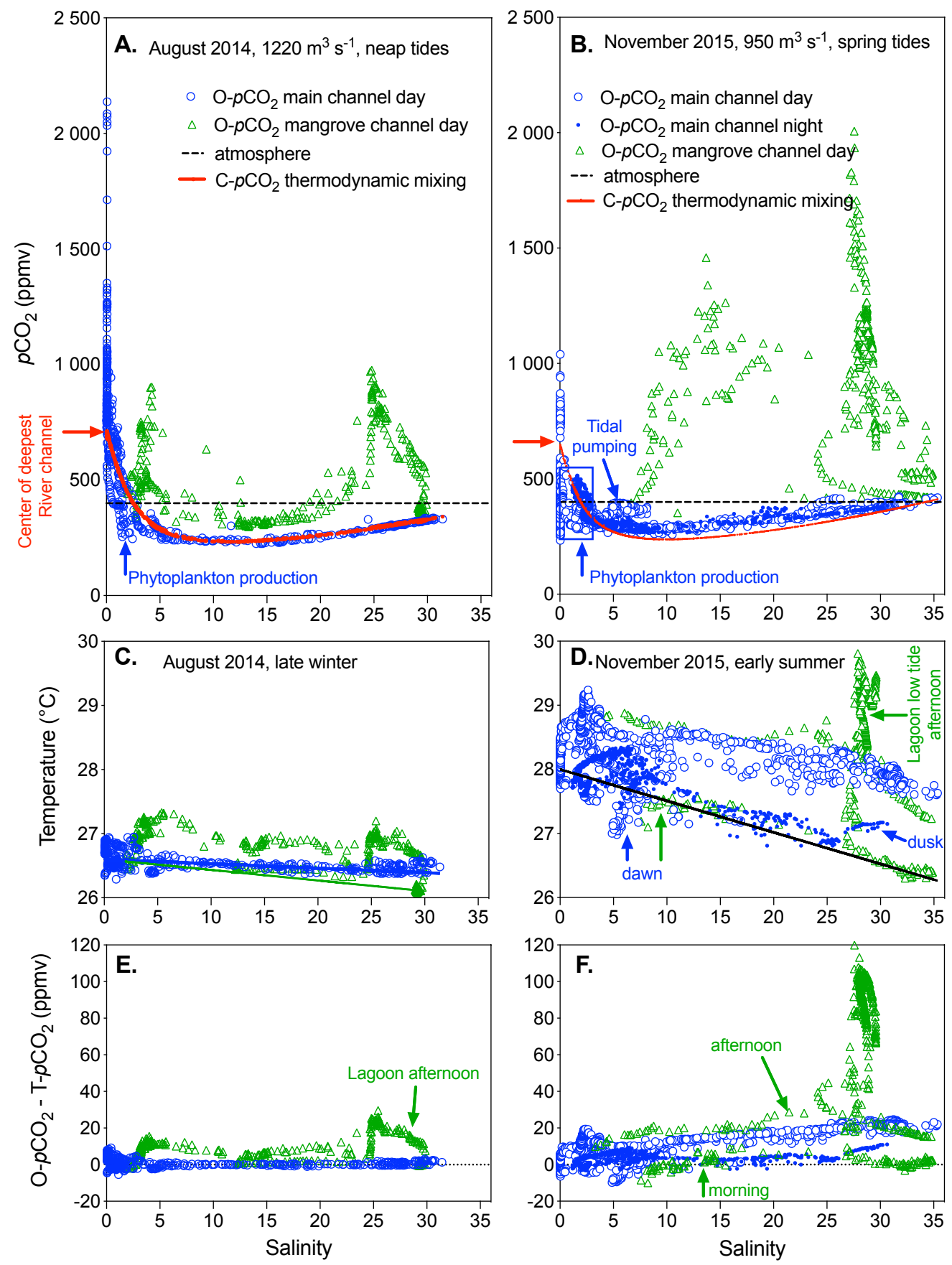

Figure 3. Distribution of $\mathrm{O}-\mathrm{pCO}_{2}$ (A. and B.), temperature (C. and D.), and the difference between O- $p \mathrm{CO}_{2}$ and $\mathrm{T}-p \mathrm{CO}_{2}$ (E. and F.) versus salinity in the São Francisco Estuary main channel (blue

29 circles) and mangrove secondary channel (green triangles). The regression lines in panel C

30 indicate the conservative mixing for temperature used for $\mathrm{pCO}_{2}$ temperature normalization in the

31 main channel (blue) and in the secondary mangrove channel (green) with a distinct marine end-

32 member in the lagoon. The black regression line in panel $D$ indicates the conservative mixing for

33 temperature in the main channel and in the secondary mangrove channel with the same values in

34 both marine end-members (see "results"). 

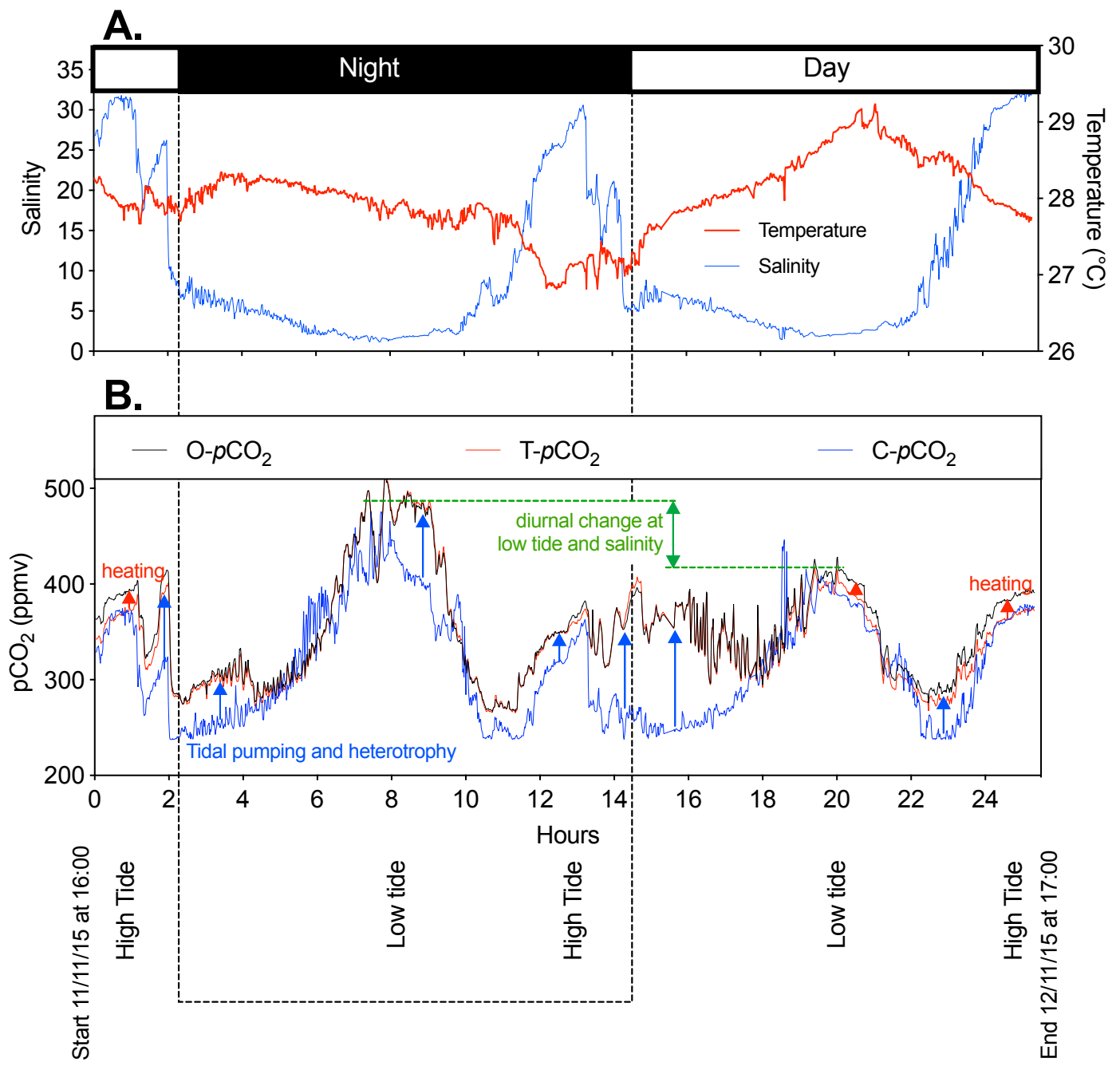

37 Figure 4. Time course of physico-chemical parameters in surface water of the main channel of the

38 São Francisco River Estuary during the 25h cycle in Nov. 2015 (summer and spring tides). (A.)

39 Temperature and Salinity and (B.) measured $\mathrm{O}-\mathrm{pCO}_{2}$ (black line), temperature-normalised T- $p \mathrm{CO}_{2}$

40 (red line), and the $\mathrm{C}-\mathrm{pCO}$ induced by conservative mixing of seawater with freshwater calculated

41 from the salinity record (blue line). Upward blue arrows indicate the occurrence of tidal pumping,

42 net heterotrophy and gas exchange (invasion of atmospheric $\mathrm{CO}_{2}$ ). Upward red arrows indicate the

43 impact of heating on $\mathrm{pCO}_{2}$. Green double arrows indicate the significant diurnal change in low

44 salinity waters. 

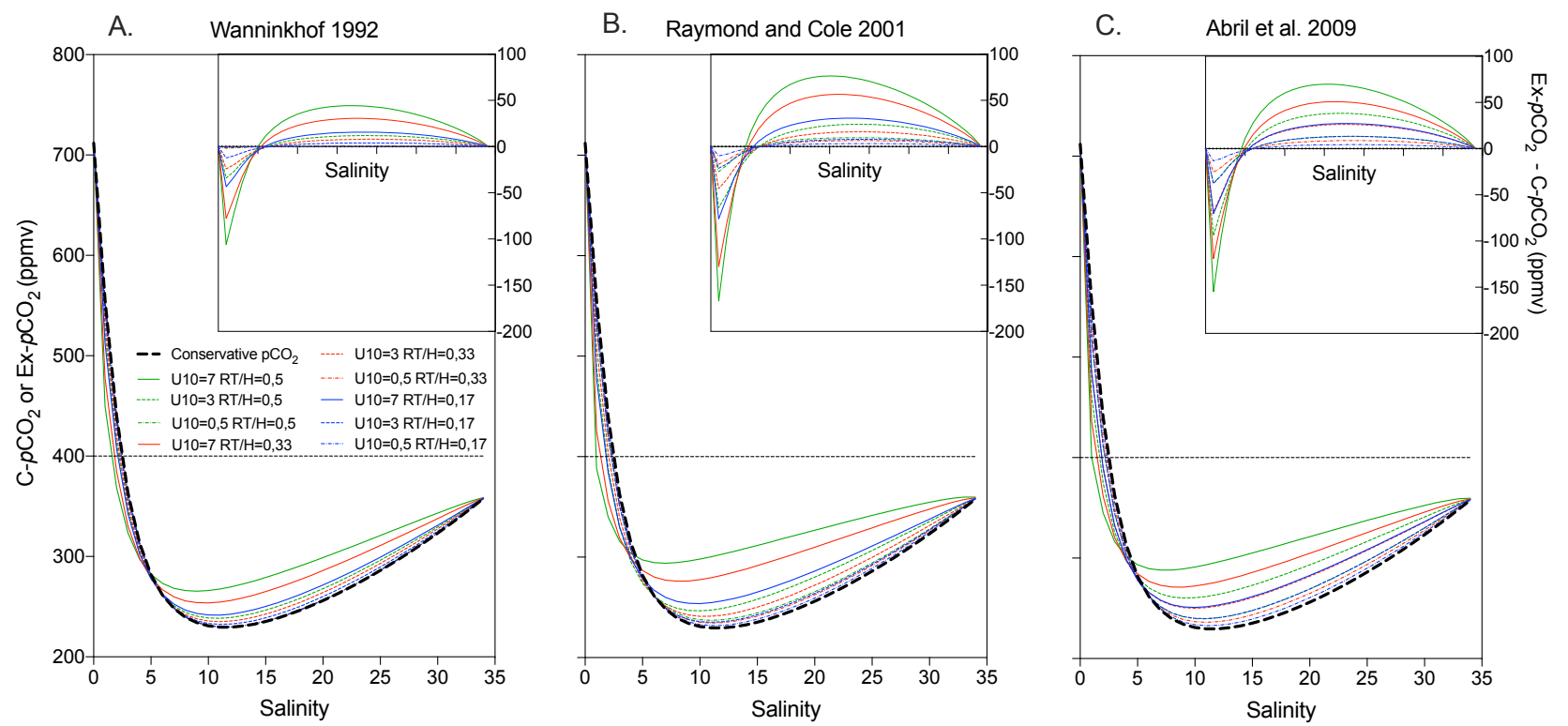

53 Figure 5. Impact of air-water $\mathrm{CO}_{2}$ exchange on thermodynamic conservative $\mathrm{pCO}_{2}$ mixing curves.

54 Calculations were made using Temperature, Salinity, DIC and TA observed in the freshwater and

55 marine end-members in Nov. 2015 and the gas exchange was computed every salinity unit

56 increment (see section 2.2). RT/H is the ratio between residence time and water depth, and the

57 selected value of 0,17 is representative for estuarine systems such as the São Francisco, whereas

58 the value may apply to larger tropical rivers such as the amazon or congo.

59

60 

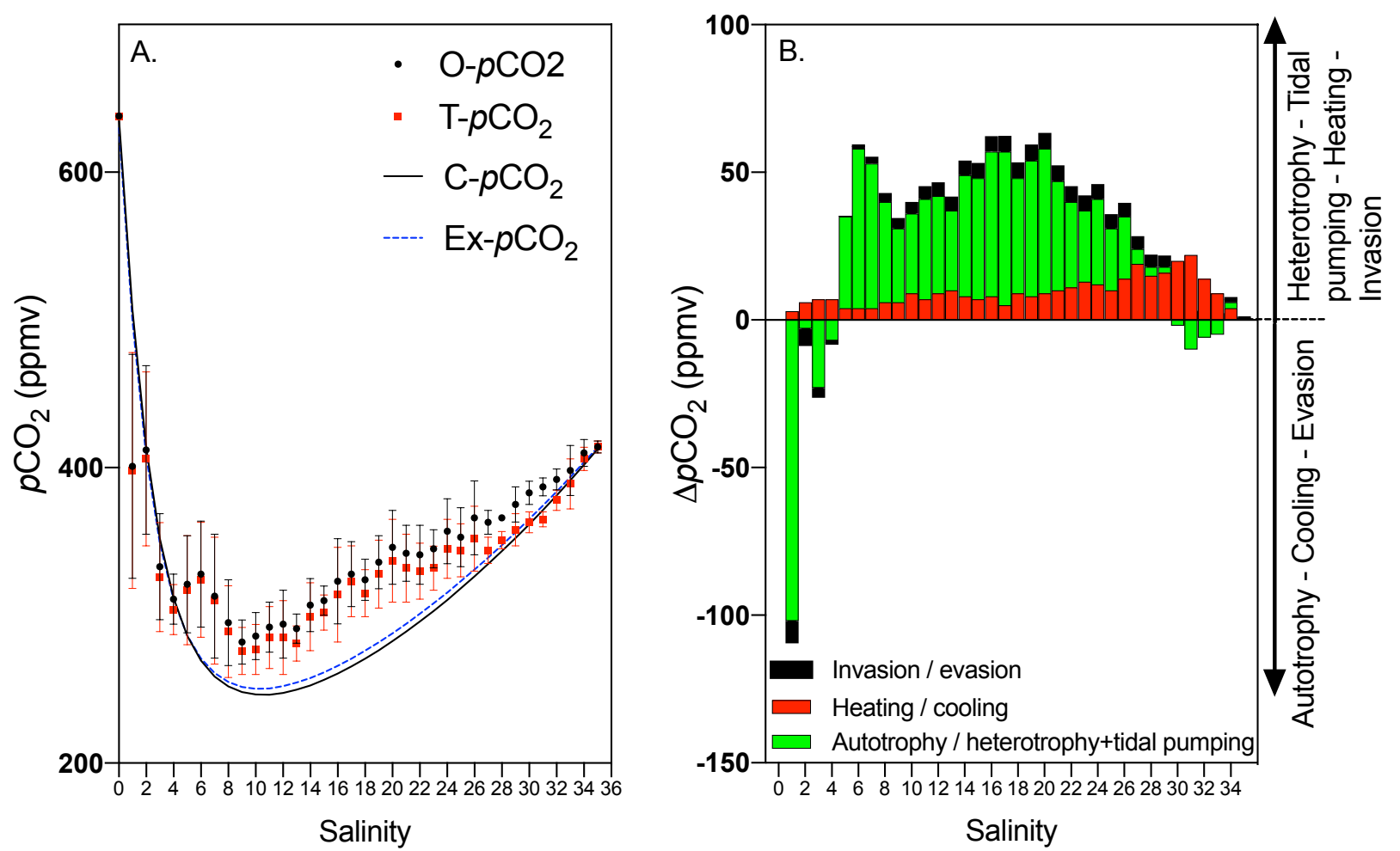

63 Figure 6. Comparison between measured and modelled $\mathrm{pCO}_{2}$ along the salinity gradient of the São Francisco Estuary during the summer and spring tide cruise in Nov. 2015. A: measured O$p \mathrm{CO}_{2}$ binned for one salinity increments (blue dots with standard deviations as error bars), T- $p \mathrm{CO}_{2}$ normalized to a temperature corresponding to the conservative mixing of river and sea waters (red dots with standard deviations as error bars), modelled $\mathrm{C}-\mathrm{pCO} \mathrm{C}_{2}$ by considering the conservative mixing of TA, DIC and temperature in waters from the river and the sea (black full line), and modelled Ex- $p \mathrm{CO}_{2}$ for conservative mixing corrected for gas exchange (blue dashed line). $\mathrm{B}$ : residual between the modelled and observed $\mathrm{pCO}_{2}$. Invasion or evasion (black bars) is calculated as the difference between the $\mathrm{C}-\mathrm{pCO}$ and $\mathrm{Ex}-\mathrm{pCO} \mathrm{CO}_{2}$ curves. Heating or cooling (red bars) is calculated as the difference between the $\mathrm{O}-\mathrm{pCO}_{2}$ and $\mathrm{T}-\mathrm{pCO}$. Autotrophy or heterotrophy and tidal pumping (green bars) is calculated as the residual, i.e. as the difference between the T- $p \mathrm{CO}_{2}$ $\mathrm{Ex}-\mathrm{pCO}$. 
78 Supplementary Material

79

80 Figure S1.

81
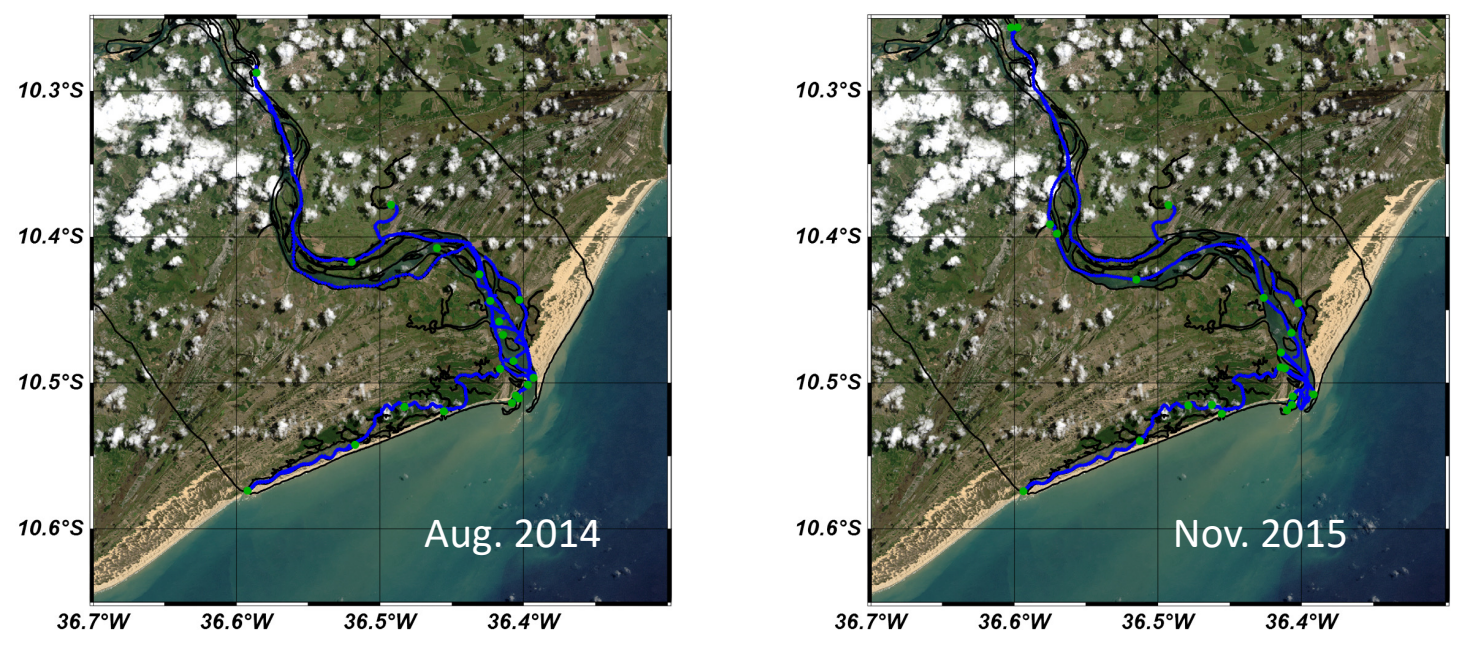

82

83 Figure S1. Track of the boat (blue lines) and discrete sampling (green dots) during the two field 84 trips.

85 

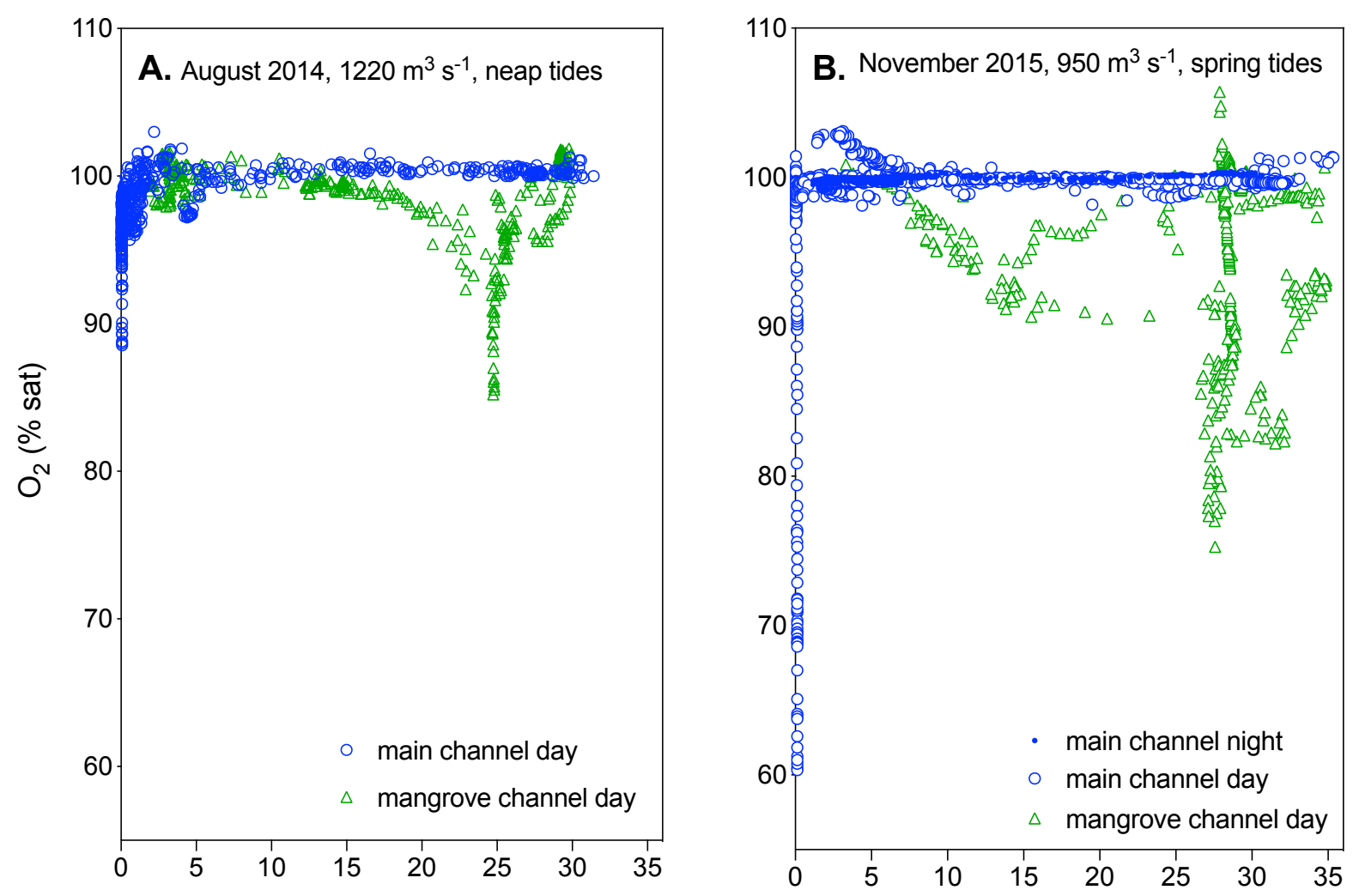

90 Figure S2. Distribution of dissolved oxygen (in percent of saturation) versus salinity in the São

91 Francisco Estuary main channel (blue circles) and mangrove secondary channel (green triangles)

92 in Aug. 2014 (A) and Nov. 2015 (B).

93

94 